\title{
Interaction of an $\alpha$-synuclein epitope with HLA-DRB1*15:01 initiates early enteric features of Parkinson's disease in humanized mice
}

Francesca Garretti $^{1,2,9}$, Connor Monahan ${ }^{2,9}$, Nicholas Sloan ${ }^{3}$, Sanjid Shariar ${ }^{1}$, Seon Woo Kim ${ }^{4}$, Alessandro Sette ${ }^{4,5,9}$, Tyler Cutforth ${ }^{7,9}$, Ellen Kanter $^{2,8}$, Dritan Agalliu ${ }^{1,7,9 *}$ and David Sulzer ${ }^{2}$ $7,8,9 *$

1. Department of Pathology and Cell Biology, Columbia University Irving Medical Center, New York, NY, USA.

2. Departments of Psychiatry and Pharmacology, Columbia University Irving Medical Center, New York, NY, USA.

3. Department of Neuroscience, Columbia University Irving Medical Center, New York, NY, USA.

4. Weill Cornell Medicine-Qatar, Education City, Doha, Qatar.

5. Division of Vaccine Discovery, La Jolla Institute for Immunology, La Jolla, CA, USA.

6. Department of Medicine, University of California in San Diego, San Diego, CA, USA.

7. Department of Neurology, Columbia University Irving Medical Center, New York, NY, USA.

8. Division of Molecular Therapeutics, New York State Psychiatric Institute, New York, NY, USA.

9. Aligning Science Across Parkinson's (ASAP) Collaborative Research Network, Chevy Chase, MD, 20815

* Equal contribution senior authors

Correspondence: $\quad$ Dr. David Sulzer Ph.D., ds43@cumc.columbia.edu
Dritan Agailliu, Ph.D

da191@cumc.columbia.edu 


\section{SUMMARY}

Parkinson's disease (PD) patients possess circulating T cells that recognize specific $\alpha$-synuclein( $\alpha$-syn)-derived epitopes. One epitope, $\alpha$-syn $32-46$, interacts strongly with the HLA-DRB1*15:01 allele implicated in multiple autoimmune diseases. Whether this interaction and $\alpha$-syn-specific $\mathrm{T}$ cells play roles in PD pathogenesis remains unknown. We report that $\alpha$-syn $32-46$ immunization of a humanized mouse that expresses HLA-DRB1*15:01 triggers intestinal inflammation. This enteric pathology is characterized by activation of innate and adaptive immune responses and type I interferon signaling as well as loss of enteric dopaminergic neurons in the submucosal plexus, and results in constipation and weight loss. Depletion of $\mathrm{CD}^{+}$, but not $\mathrm{CD}^{+}, \mathrm{T}$ cells partially rescues enteric neurodegeneration. Thus, an interaction between $\alpha$-syn $32-46$ and HLA-DRB1*15:01 induces gut inflammation and $\mathrm{CD}^{+} \mathrm{T}$ cell-mediated loss of enteric dopaminergic neurons in the humanized mice. These findings suggest a mechanism for the prodromal enteric features of PD and indicate future directions for disease screening and treatment.

\section{KEYWORDS}

Parkinson's disease, $\alpha$-synuclein, neo-antigen, HLA-DRB1*15:01, prodromal disease, enteric dopaminergic neurons, constipation, $\mathrm{CD}^{+} \mathrm{T}$ cells.

\section{HIGHLIGHTS AND eTOC Blurb}

1. $\alpha-$ syn $_{32-46}$ immunization of a HLA-DRB1*15:01 mouse triggers weight loss and constipation. 
2. $\alpha-\operatorname{syn}_{32-46}$ immunizations induce gut inflammation and loss of enteric dopaminergic neurons.

3. Depletion of $\mathrm{CD}^{+}$, but not $\mathrm{CD}^{+}$, $\mathrm{T}$ cells partially rescues enteric neurodegeneration.

4. Interaction between $\alpha-\operatorname{syn}_{32-46}$ and HLA-DRB1*15:01 are critical for the prodromal phase of PD.

Parkinson's disease (PD) patients have circulating T cells that recognize $\alpha$-synuclein-( $\alpha$-syn)epitopes. One epitope $\alpha$-syn $32-46$, interacts with the HLA-DRB1*15:01; however, its role in PD pathogenesis remains unknown. Garretti et al. show that $\alpha$-syn $32-46$ immunization of a humanized mouse expressing HLA-DRB1*15:01 triggers intestinal inflammation, loss of enteric dopaminergic neurons, constipation and weight loss, suggesting a critical role in the prodromal PD. 


\section{INTRODUCTION}

Parkinson's disease (PD) is a neurodegenerative disorder characterized by prominent motor symptoms resulting from the loss of central nervous system (CNS) dopaminergic neurons located in the substantia nigra (SN) (Fahn and Sulzer, 2004). However, the death of these neurons is suspected to occur at relatively late stages of disease pathogenesis. In contrast, enteric nervous system (ENS) symptoms often occur during an earlier prodromal stage of the disease (Heinzel et al., 2019). Constipation presents in approximately 70\% of PD patients (Fasano et al., 2015), is three-fold more prevalent in PD patients than healthy controls (Drossman, 2006), and may occur as early as twenty years prior to the onset of motor symptoms (Khoo et al., 2013). Although epidemiological studies have demonstrated a high prevalence of constipation in PD patients [reviewed in (Fasano et al., 2015)] and postmortem studies have found that gut pathology is present before the onset of motor symptoms (Braak et al., 2003; Stokholm et al., 2016), the mechanisms underlying the enteric pathophysiology remain unclear.

Braak and colleagues have hypothesized that $\alpha$-synuclein ( $\alpha$-syn) -mediated pathology begins in the ENS and later ascends rostrally into the brain via the vagus nerve (Braak et al., 2003). This conjecture is consistent with reports that truncal vagotomies decrease the risk for PD (Liu et al., 2017; Svensson et al., 2015; Tysnes et al., 2015). Epidemiological clinical studies support a role for gut inflammation in early stages of PD. The incidence of PD among patients with inflammatory bowel disease (IBD) is $28 \%$ higher than controls. Furthermore, IBD patients who receive anti-TNF $\alpha$ therapy exhibit a $78-100 \%$ reduction in PD incidence compared to those who do not receive such therapy (Park et al.; Peter et al., 2018). Multiple observations in animal models are also consistent with the hypothesis that gut inflammation, in some cases related to $\alpha$-syn 
depositions, may be involved in early stages of PD-like pathogenesis [reviewed in (Metzger and Emborg, 2019)].

A possible role for peripheral inflammation in PD pathogenesis is suggested by findings that increased levels of pro-inflammatory cytokines (e.g., TNF $\alpha$, IL-1 $\beta$, IL-6 and IFN $\gamma$ ) are found in PD patients and correlate negatively with disease duration (Cossais et al., 2021; Devos et al., 2013; Pochard et al., 2018; Qin et al., 2016). PD patients also possess circulating T cells, mostly $\mathrm{CD}^{+}$subtypes, that recognize specific $\alpha$-syn-derived neo-epitopes (Sulzer et al., 2017). Quantification of these lymphocytes over the course of PD suggests that $\alpha$-syn-specific T cells are abundant prior to the onset of motor symptoms and clinical diagnosis, but subsequently decrease a decade after disease confirmation (Lindestam Arlehamn et al., 2020). Thus, $\alpha$-syn neo-antigen reactivity may be relevant to the prodromal and early stages of disease and not simply a downstream consequence of neuronal loss in the CNS [reviewed in (Garretti et al., 2019)].

Previously, we reported that $\alpha$-syn-responsive $\mathrm{CD}^{+} \mathrm{T}$ cells isolated from PD patients respond to two major regions of the protein (Sulzer et al., 2017). One region requires the presence of phosphorylated amino acid serine 129 (Sulzer et al., 2017), a post-translational modification present at high levels in Lewy bodies (Fujiwara et al., 2002). However, these C-terminal epitopes bind weakly to multiple human leukocyte antigen (HLA) alleles, indicating that they are "unrestricted". The other major $\alpha$-syn epitope identified in PD patients is the $\alpha$-syn $32-46$ region, which lies in proximity to several rare $\alpha$-syn mutations that cause familial PD (Appel-Cresswell et al., 2013; Ki et al., 2007; Kruger et al.; Lesage et al., 2013; Liu et al., 2021; Pasanen et al., 2014; Polymeropoulos et al., 1997; Yoshino et al., 2017; Zarranz et al., 2004). In contrast to the C- 
terminal epitopes, the $\alpha-\mathrm{syn}_{32-46}$ epitope is highly restricted to a specific HLA haplotype [B*07:02, C*07:02, DRB5*01, DRB1*15:01, DQA1*01:02, DQB1*06:02], expressed by approximately one third of the population (Sulzer et al., 2017). Moreover, there is a very strong binding affinity $(\mathrm{Kd}=2.8 \mathrm{nM})$ of the peptide to HLA-DRB1*15:01 in vitro (Sulzer et al., 2017). Independent genome-wide association studies (GWAS) have also reported that this haplotype is associated with PD (Hamza et al., 2010; Hill-Burns et al., 2011; Kannarkat et al., 2015).

Despite these findings, it is unknown how the interaction between this $\alpha$-syn epitope $(\alpha-$ $\left.\operatorname{syn}_{32-46}\right)$ and HLA allele (DRB1*15:01) may trigger PD pathogenesis. Here, we report that $\alpha$ syn $_{32-46}$ peptide immunizations of a mouse strain lacking the mouse MHC-II alleles and expressing the human HLA-DRB1*15:01 allele trigger intestinal inflammation characterized by activation of innate and adaptive immune responses and type I interferon signaling, as well as loss of enteric dopaminergic neurons in the submucosal plexus of the small intestine, leading to constipation and weight loss. These enteric pathologies and symptoms are not observed in wild-type mice immunized with the same peptide, suggesting a specificity of the immune response. Depletion of $\mathrm{CD}^{+}$, but not $\mathrm{CD}^{+}$, T cells partially rescues enteric neurodegeneration. Thus, interactions of $\alpha-$ $\operatorname{syn}_{32-46}$ antigen with the HLA-DRB1*15:01 allele are critical to induce gut inflammation and $\mathrm{CD}^{+} \mathrm{T}$ cell-mediated loss of enteric dopaminergic neurons in the HLA-DRB1*15:01-expressing mice, suggesting a critical role for $\alpha$-syn-mediated immune mechanisms in pathogenesis of the prodromal stages of PD.

\section{RESULTS}


$\alpha-\mathrm{Syn}_{32-46}$ peptide immunizations cause severe weight loss and constipation in HLADRB1*15:01, but not wild-type, mice.

Previously, we have shown that $\mathrm{CD}^{+} \mathrm{T}$ cells isolated from PD patients carrying the HLADRB1*15:01 allele confer a strong immune response to the $\alpha$-syn $32-46$ region of the protein (Sulzer et al., 2017). To test if anti- $\alpha-\mathrm{syn}_{32-46}$ immune responses identified in PD patients can produce features of PD pathology in mice, we performed active immunizations by adapting a protocol similar to the myelin oligodendrocyte glycoprotein ( $\left.\mathrm{MOG}_{35-55}\right)$ experimental autoimmune encephalomyelitis (EAE) mouse model for human multiple sclerosis (Oh et al., 2018). Mice were immunized with either PBS/CFA (complete Freund's adjuvant), full length $\alpha$-syn protein/CFA or $\alpha$-syn $32-46$ peptide/CFA. Bordetella pertussis (B. pertussis) toxin was administered intravenously at 14 and 16 days post-immunization (DPI) to transiently open the blood-brain barrier (Figure 1A). These immunizations were performed either in $\mathrm{C} 57 \mathrm{BL} / 6 \mathrm{~J}$ [referred to herein as wild-type (WT)] mice or a humanized mouse strain lacking the mouse MHC-II alleles and expressing the human HLA-DRB1*15:01 allele [referred to as the HLA mice (Finn et al., 2004; Khare et al., 2005)]. We confirmed that splenocytes from HLA-DRB1*15:01 mice expressed HLA-DR protein and that expression was increased when these cells are exposed to lipopolysaccharide (LPS) (Figure S1). Mice were monitored daily for overt signs of malaise or weight changes and classified as sick if they lost more than $12 \%$ of the initial body weight and/or exhibited hunched posture with ungroomed and "ruffled" fur (Figure 1B-E).

Following immunizations, very few WT mice became sick regardless of the antigen used for immunization ( $0 \%$ of CFA alone, $7 \% \alpha$-syn protein, $4 \% \alpha$-syn $32-46$ peptide; Figure 1B). In contrast, while full length $\alpha$-syn protein produced no illness in HLA mice, $25 \%$ of HLA mice 
immunized with the $\alpha-\operatorname{syn}_{32-46}$ peptide became ill or died (Figure 1B). The sick $\alpha-$ syn $_{32-46^{-}}$ immunized HLA mice exhibited severe weight loss starting at 14 DPI that peaked at 22- 24 DPI, with a mean weight change of $\sim 11.92 \%$ at 22 DPI $(p=0.0272)$ and $\sim 12.70 \%$ at 24 DPI $(p=0.0456)$ (Figure 1E). However, this phenotype was transient, and sick HLA-immunized mice restored their initial weight between 24 and 29 DPI, with no further weight gain (Figure 1E).

As constipation is often an early symptom associated with PD that occurs up to 20 years prior to the onset of motor symptoms (Khoo et al., 2013), we assessed total gastrointestinal transit time in either CFA- or $\alpha$-syn32-46-immunized WT and HLA mice by measuring the time required for a non-absorbed red dye to be excreted with feces after oral administration (Figure 2A, B). We selected three times points after immunization (DPI; 21, 25 and 35) to correlate this phenotype with weight loss (Figure 1E). The average total GI transit time was significantly longer in $\alpha-\mathrm{syn}_{32}$ 46- compared to CFA-immunized HLA mice at 21 DPI $(p=0.0493$; Figure 2C); however, this phenotype recovered by 25 and 35 DPI (Figure 2E, F), mirroring the recovery from weight loss (Figure 1E). Notably, the subset of $\alpha$-syn $32-46$-immunized HLA mice with significant weight loss showed a longer GI transit time ( $<<0.0001$; Figure 2D), with a significant negative correlation between the two phenotypes (peak weight loss and GI transit time; $r=-0.5643, p=0.0077$; Figure 2H) that was not observed in CFA-immunized HLA mice (peak weight loss and GI transit time; $\mathrm{r}=0.3188, \mathrm{p}=0.1707$; Figure 2G). In contrast, all immunized WT mice exhibited normal total GI transit times (Figure 2I), indicating specificity of the immune response to the DRB1*15:01 allele and $\alpha$-syn $32-46$. Thus, the combination of $\alpha-$ syn $_{32-46}$ peptide and HLA-DRB1*15:01 expression promotes acute gastrointestinal illness between 22-24 DPI. 


\section{$\alpha-S_{32-46}$-immunized HLA mice exhibit gut inflammation and loss of dopaminergic neurons} in the enteric, but not central, nervous system.

The weight loss associated with constipation observed in $\alpha$-syn $32-46$-immunized HLA mice suggests an inflammatory response targeting the gut. To examine gut pathology in detail, we prepared flat mounts of the submucosal and myenteric plexuses of the ileum of the small intestine, the region that possesses the highest concentration of dopaminergic neurons (Li et al., 2004), from immunized HLA mice at 28 DPI (Figure 3A). While the myenteric plexus is relatively segregated from circulating immune cells by prominent muscle layers, the submucosal plexus is exposed to both resident and circulating immune cells including $\mathrm{T}$ lymphocytes (Figure 3B) (Yoo and Mazmanian, 2017). We immunolabeled and quantified $\mathrm{Iba}^{+} / \mathrm{CD} 8^{+}$macrophages in these layers

(Figure 3C-F, K, L). There was a significantly higher density of $\mathrm{CD}^{6} 8^{+}$macrophages in both the myenteric ( $p=0.0448$; Figure 3C, D, K) and the submucosal $(p=0.0341$, Figure 3E, F, L) plexuses of the ileum in $\alpha-$ syn $_{32-46-}$ than in CFA-immunized HLA mice.

To investigate whether the ENS inflammation was associated with neuronal loss, we analyzed expression of ANNA1, a marker for neuronal nuclei, and tyrosine hydroxylase (TH) as a marker for catecholaminergic neurons, which are mainly dopaminergic in the ileum (Li et al., 2004). The density of $\mathrm{ANNA1}^{+}$and $\mathrm{TH}^{+}$neurons was similar in CFA- and $\alpha-\mathrm{syn}_{32-46}$-immunized HLA mice in the myenteric plexus (Figure 3G, H, M, N). However, $\alpha$-syn $32-46$-immunized HLA mice had fewer dopaminergic neurons $(p=0.0408)$ and ANNA- $1^{+}$neurons $(p=0.0058)$ in the submucosal plexus than CFA-immunized HLA mice (Figure 3I, J, O, P) and the area of the $\mathrm{TH}^{+}$

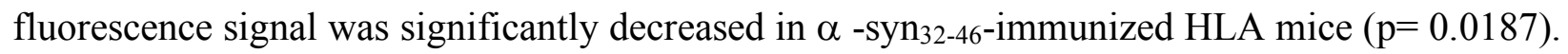
In contrast, although there was a trend of reduced $\mathrm{TH}^{+}$mean fluorescence intensity (MFI) within 
neuronal cell bodies and processes at 28 days, it did not reach significance by parametric analysis $\left(\mathrm{p}=0.1496\right.$; Figure 3Q, R). We conclude that $\alpha-\operatorname{syn}_{32-46}-$ HLA-DRB1*15:01 interactions are necessary to induce loss of enteric dopaminergic neurons and inflammation in the ileum ENS of HLA mice.

The loss of SN dopaminergic neurons, neuroinflammation and prominent motor symptoms are central features of PD (Fahn and Sulzer, 2004), and so we examined whether $\alpha$-syn $32-46^{-}$ immunized HLA mice that show weight loss and constipation exhibit CNS pathology. In contrast to the pronounced inflammation and loss of ENS neurons in the gut, $\alpha-$ syn $_{32-46}$ immunizations did not induce $\mathrm{CD}^{+} \mathrm{T}$ cell infiltration in the brains of either WT or HLA mice, up to two months after the boost (70 DPI; Figure S2A-K). Moreover, there were no signs of neuroinflammation (i.e., microglia activation or macrophage infiltration, or loss of SN dopaminergic neurons (Figure S2LO). Consistent with the lack of CNS pathology, neither WT nor HLA mice displayed any motor behavior or learning deficits after $\alpha-\mathrm{syn}_{32-46}$ immunizations (Figure S3). The lack of CNS CD3 ${ }^{+}$ T lymphocyte infiltration, neuroinflammation or neurodegeneration and the absence of any motor skill and learning abnormalities indicate that the severe weight loss and constipation found in $\alpha$ syn32-46-immunized HLA mice were not related to changes in basal ganglia circuits.

\section{Dopaminergic neuron loss in the gut corresponds to weight loss in $\alpha$-syn $32-46$ - immunized}

\section{HLA mice}

To uncover the chronology between gut inflammation, ENS neuronal death and weight loss in $\alpha$-syn $32-46$-immunized HLA mice, we analyzed the number of $\mathrm{TH}^{+}$neurons in the myenteric and submucosal plexuses at 18 and 42 DPI (Figure 4A and B), prior to and after the weight loss 
(Figure 1E). There was no difference in the number of dopaminergic neurons and $\mathrm{TH}^{+}$ fluorescence signal in the submucosal plexus between CFA and $\alpha$-syn $32-46$-immunized HLA mice at 18 DPI (Figure 4E, F, J-L). By 42 DPI, the area and MFI of the $\mathrm{TH}^{+}$signal were both significantly reduced in $\alpha$-syn $32-46$-immunized mice $(p=0.0135$ and $p=0.0066$, respectively;

Figure 4U, V), although there was no significant difference in the number of dopaminergic neuron cell bodies in the submucosal plexus ( $p=0.226$; Figure 4O, P, T). Thus, the time course analysis indicates that dopamine neuron loss in the submucosal plexus of $\alpha$-syn $32-46$ - immunized HLA mice begins after 18 DPI, peaks at 28 DPI, and stabilizes or possibly recovers by 42 DPI (Kulkarni et al., 2017). In contrast, in the myenteric plexus, the number of dopaminergic neurons was unaltered at 18 (Figure 4C, D, I) and 42 DPI (Figure 4M, N, S), indicating that these neurons are not lost

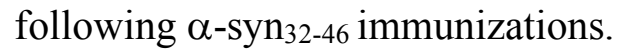

We then analyzed the number of macrophages at 18 and 42 DPI. In contrast to the 28 DPI (Figure 3K, L), there was no significant difference in the number of macrophages in the myenteric and submucosal plexuses at 18 and 42 DPI between CFA and $\alpha$-syn $32-46$-immunized HLA mice (Figure 4C-H, M-R). Thus, inflammation is transiently elevated in the ileum between 18 - 28 DPI and subsides by 42 DPI.

$\alpha-\operatorname{Syn}_{32-46}$ immunizations activate both innate and adaptive immune response pathways in the gut

To investigate the mechanisms of gut inflammation in $\alpha$-syn $32-46$-immunized HLA mice, we performed bulk RNA sequencing and differential expression analysis of the ileum between $\alpha$ syn $_{32-46}$ - and CFA-immunized HLA mice at $21 \mathrm{DPI}$, during the period of maximum inflammation. 
Differential expression analysis identified 143 significantly upregulated and 54 significantly downregulated genes in $\alpha$-syn $32-46$ - compared to CFA-immunized HLA mice (Figure 5A; padj < 0.05 and $\log _{2} f c>|0.5|$; Table S1, S2). Gene ontology (GO) enrichment analysis using the Database for Annotation, Visualization and Integrated Discovery (DAVID) revealed several significant GO terms representing genes of similar functional characteristics for the genes upregulated in $\alpha-\mathrm{syn}_{32}$ 46 -immunized HLA mice (Figure 5B) including: a) the innate immune response (e.g. GO: 0045087, FDR $=2.34 \times 10^{-25}$ Figure 5B, C); b) interferon-stimulated genes (ISG) including Stat1/2, Oas2, Irf7, and Isg15, that play mutliple roles in defense against invading pathogens (Figure 5B, E); c) the response to interferon- $\beta$ (GO: 0035456, FDR $=3.64 \times 10^{-15}$; Figure 5B, E). The response to cytokines $\left(\mathrm{GO}: 0034097, \mathrm{FDR}=3.54 \times 10^{-16}\right)$ was significantly upregulated, including ISGs, several chemokines (e.g., Cxcl10 and Cxcl13) and Vcam1, a cell adhesion molecule involved in immune cell adhesion to blood vessels (Figure 5B, D). Additional genes involved in lymphocyte-mediated (adaptive) immunity were also significantly enriched (GO: 0002449, FDR $=0.00593$ ), including the upregulation of genes involved in antigen processing and presentation via MHC class I (Tap1, H2.T24, H2.Q6, H2.T22, H2.T23) (Figure 5B, F). Finally, the humoral immune response was identified as a significant GO term $(\mathrm{GO}$ : 0002455, FDR = 0.0495) with upregulation of genes encoding for the immunoglobulin heavy chain and components of the complement cascade (Figure 5B, D, F). We conclude that $\alpha$-syn $32-46$ immunization in HLA mice upregulates both innate and adaptive immunity in the ileum at $21 \mathrm{DPI}$, consistent with the transient inflammation due to the combination of the $\alpha$-syn peptide and the HLA allele.

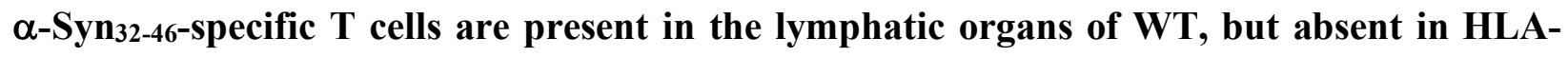
DRB1*15:01 mice. 
To determine if $\alpha$-syn $32-46$ peptide immunizations produce an antigen-specific immune response in HLA DRB1*15:01 mice, we isolated spleen and cervical and axillary lymph node cells from either WT or HLA mice at 28 DPI after immunizations with either CFA alone, syn s2-46 $_{\text {peptide }}$ or full protein (Figure S4A, S5A). Cells were stimulated in vitro with either the antigen, PBS or Concavalin A (ConA) as respective negative and positive controls for 48 hours. We then measured IFN $\gamma$ and IL-17A levels, since these cytokines are secreted by Th1 and Th17 lymphocytes and are elevated in blood of PD patients (Sommer et al., 2018; Yang et al., 2014). $\alpha-$ Syn$_{32-46}$ and ConA both strongly increased IFN $\gamma$ and IL-17A secretion from WT splenocytes and lymph cells, but had little or no effect on cells obtained from CFA or $\alpha$-syn $32-46$-immunized HLA mice $(p=0.0691$;

Figure S4B, C, G, H; data not shown). Similar results were obtained with $\alpha$-Syn protein immunizations (Figure S5). The low levels of IFN $\gamma$ secreted by $\alpha-\mathrm{syn}_{32-46}$ - immunized HLA splenocytes were released primarily by CD4- CD8- cells $(p<0.0001)$, in contrast to the response of WT splenocytes after in vitro re-stimulation with $\alpha-\mathrm{syn}_{32-46}$, which was largely driven by $\mathrm{CD}^{+} \mathrm{T}$ cells ( $p=0.0160$; Figure S4D-F). Together, these findings suggest that $\mathrm{CD} 4^{+} \mathrm{T}$ cells that secrete IFN $\gamma$ and IL-17 are no longer present in the spleens or lymph node cells of immunized HLA mice at 28 days after immunization, a response consistent with either their release from these organs or loss due to cell death after in vitro re-activation of an immune response.

To determine whether HLA mice can induce a humoral immune response following $\alpha$ syn $_{32-46}$ immunizations, we assessed the levels of antibodies that recognize $\alpha-$ syn $_{32-46}$ from blood

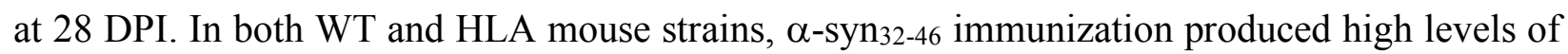
antigen-specific antibodies (Figure S4I). As expected, the full length $\alpha$-syn protein immunizations produced antibodies to multiple regions of the protein in both WT and HLA mice and a higher 
antibody titer than $\alpha$-syn $32-46$ immunizations $(\mathrm{p}<0.0001)$ : notably, however, the full length $\alpha$-syn protein immunization did not elicit production of antibodies that recognize the $\alpha$-syn $32-46$ peptide (Figure S5I).

Together, the results from lymph and spleen cells as well as antibody production confirm that following $\alpha-\operatorname{syn}_{32-46}$ immunizations of DRB1*15:01 HLA expressing mice, the $\alpha-$ syn $_{32-46}$ specific $\mathrm{T}$ cells are likely expelled from peripheral lymphoid organs, consistent with the redistritubion of antigen-specific $\mathrm{T}$ cells to the enteric system.

\section{$\mathrm{CD4}^{+} \mathrm{T}$ cells are partially responsible for the ENS dopaminergic neuron death}

To examine which $\mathrm{T}$ cell subtypes are critical for the $\alpha$-syn $32-46$ immunization-driven enteric inflammation, neurodegeneration and constipation in HLA mice, we depleted either CD4 ${ }^{+}$ or $\mathrm{CD}^{+} \mathrm{T}$ cells with anti-CD4, anti-CD8, or isotype control antibodies administered before and at weekly intervals after $\alpha-\mathrm{syn}_{32-46}$ immunization (Figure 6A). Flow cytometry analysis of peripheral blood showed that the appropriate antibody treatments depleted $\mathrm{CD}^{+}$and $\mathrm{CD}^{+} \mathrm{T}$ cell types in mice (Figure 6B).

A large proportion ( $\sim 64 \%)$ of a-syn32-46 -immunized HLA mice treated with the IgG isotype control did not survive to $42 \mathrm{DPI}$, while nearly all CD4 $4^{+}$- or $\mathrm{CD} 8^{+}$- depleted $\alpha$-syn $32-46$ - immunized HLA mice survived until sacrifice (Figure 6C, D). Weight monitoring revealed no significant difference in weight loss across all treatment groups (Figure 6E). All groups showed similar GI transit times (Figure 6F) and there was no significant difference in macrophages in either myenteric and submucosal plexuses (Figure 6J, L). Importantly, histopathological analysis 
revealed a rescue of $\mathrm{TH}^{+}$neurons in the submucosal, but not myenteric, plexus of $\mathrm{CD}^{+}$-depleted $\alpha-\operatorname{syn}_{32-46}$ immunized HLA mice, but no rescue by the depletion of CD8 ${ }^{+} \mathrm{T}$ cells (Figure $\mathbf{6 G}, \mathbf{H}$ ). Interestingly the neuronal loss appeared to be specific to $\mathrm{TH}^{+}$cells, as other ENS neurons remained unchanged across all treatment groups. Thus, $\mathrm{CD}^{+} \mathrm{T}$ cells may be in part responsible for inducing $\mathrm{TH}^{+}$cell loss after $\alpha$-syn $32-46$-immunizations in HLA mice (Figure 6H). The persistence of gut inflammation observed in both plexuses following $\mathrm{T}$ cell depletions suggest that additional immune cells and/or antibodies may drive additional aspects of enteric pathophysiology following $\alpha$-syn peptide immunizations in HLA-DRB1*15:01 mice.

\section{DISCUSSION}

$\mathrm{PD}$ is a multifactorial disease; however, dysregulation of the immune response targeting $\alpha$-syn has been strongly implicated as a potential driver in disease pathogenesis, at least in a subset of PD patients (Garretti et al., 2019; Sulzer et al., 2017). Our previous studies have shown that $\mathrm{CD}^{+} \mathrm{T}$ cells that respond prominently to two regions of the $\alpha$-syn protein are found in the blood of PD patients (Sulzer et al., 2017). Although the immune response to $\alpha$-syn $32-46$ region is restricted to patients carrying a specific HLA haplotype [B*07:02 $\mathrm{C}^{*}$ 07:02 DRB5*01 DRB1*15:01 DQA1*01:02 DQB1*06:02] (Sulzer et al., 2017), how these interactions trigger PD pathogenesis is unknown.

Here, using an active immunization approach in mice, similar to induction of the EAE mouse model for human MS (Oh et al., 2018), we find that $\alpha$-syn $32-46$ peptide immunizations in mice in which their native MHC class II allele was substituted by the human HLA DRB1*15:01 
allele recapitulate multiple aspects of the immune response detected in PD patients. These include pronounced inflammation of the gut, loss of ENS neurons and dopaminergic neurons and constipation, features reminiscent of clinical gastroenterological deficits reported in PD patients twenty years prior to disease onset (Khoo et al., 2013) (Figure 7). These phenotypes depend in part on the presence of $\mathrm{CD}^{+} \mathrm{T}$ cells (Figure 6). Our findings confirm previous hypotheses that neurodegenerative effects of $\alpha-\operatorname{syn}_{32-46}$ antigen / HLA-DRB1*15:01 interactions can underlie the prodromal stages of PD manifested by prominent gut inflammation and $\mathrm{CD}^{+} \mathrm{T}$ cell-driven loss of enteric dopaminergic neurons.

While the immunizations generated a strong antibody response to $\alpha$-syn $32-46$ peptide in both WT and HLA mice, we found that $\mathrm{T}_{\mathrm{H}} 1, \mathrm{~T}_{\mathrm{H}} 17$ and CTLs that responded to the peptide were retained in spleen and axillary lymph nodes only in WT mice, and strikingly, that $\alpha-\mathrm{syn}_{32-46}-$ specific CD $^{+}$ T cells were absent in immune organs in $\alpha-$ syn $_{32-46}$ - immunized HLA mice (Figure S4). This observation is likely consistent with effective homing of these $\mathrm{CD}^{+} \mathrm{T}$ cells from dedicated immune organs to the gut, where they likely are responsible for gastrointestinal inflammation, loss of ENS neurons and constipation (Figures 2, 3 and 7).

In our humanized mouse model, constipation, a GI symptom present in the majority of PD patients, also required the combination of $\alpha-\operatorname{syn}_{32-46}$ peptide and the HLA DRB*1 15:01 allele. While other PD mouse models have reported constipation (Metzger and Emborg, 2019), our study is, to our knowledge, the first to demonstrate that a specific combination of an $\alpha$-syn-derived epitope and an HLA allele can drive gut pathology and dysmotility. This pathology is characterized by high levels of macrophage infiltration in both myenteric and submucosal plexuses (Figure 3) 
and activation of multiple innate and adaptive immune responses (Figure 5). This inflammation is followed by a loss of dopaminergic neurons in the submucosal plexus of $\alpha$-syn $32-46$-immunized HLA mice (Figures 3, 4, 7).

The results from the $\mathrm{CD}^{+}$and $\mathrm{CD}^{+} \mathrm{T}$ cell depletion studies suggest that $\mathrm{CD} 4^{+} \mathrm{T}$ cells are critical drivers of dopaminergic neurons loss in the gut, and are consistent with other studies implicating a role for $\mathrm{CD}^{+} \mathrm{T}$ cells in CNS damage in other PD mouse models (Brochard et al., 2009; Williams et al., 2021). CD4 ${ }^{+}$T cells do not classically elicit autoimmune cytotoxicity, and the mechanisms by which they mediate neuronal loss have not been elucidated. The immunedependent loss of dopaminergic neurons appears to be transient, and may be related to either a temporary loss of the TH marker expression (Harvey et al., 2000; Hotchkiss and Gibb, 1980; Soriano et al., 1997), conversion to catecholaminergic neurons as has been shown in other peripheral neurons (Coulombe and Bronner-Fraser, 1986; Wolinsky and Patterson, 1983), or generation of newborn dopamine neurons in the adult small intestine following the inflammatory injury (Kulkarni et al., 2017).

It is unclear whether features of gut pathology observed in our mouse model are present in PD, since beyond constipation, gut pathology has not been well characterized in PD patients. However, the enteric system of PD patients has been shown to be inflamed (Cossais et al., 2021; Devos et al., 2013; Pochard et al., 2018; Qin et al., 2016) and Lewy pathology has been detected in both the myenteric and submucosal plexuses (Aldecoa et al., 2015; Beach et al., 2009; Mrabet et al., 2016; Punsoni et al.). While some biopsy studies of the gut report no difference in dopaminergic neurons between PD patients and healthy controls (Annerino et al., 2012; Corbille 
et al., 2014; Lebouvier et al., 2010), enteric neurons are irregularly distributed across the two plexuses of the 25 feet-long human adult bowels (Rao and Gershon, 2016), making it challenging to sample adequately gut pathological specimens. Similar to findings in our mouse model, some ENS symptoms in PD, including constipation, might wax and wane depending on the presence of specific epitopes, particularly $\alpha-\mathrm{syn}_{32-46}$ or phosphorylated S129. Although dopamine has been shown to be essential for normal gastrointestinal motility (Li et al., 2006), it is unknown how loss of dopaminergic neurons alters enteric neuron signaling, muscle contraction, and constipation in PD patients. However, the density of enteric neurons in the small intenstine is reported to correlate with clinical features of dysmotility (Boschetti et al., 2019). A standardization of enteric biopsies and comprehensive analysis of the enteric system postmortem may shed light on the connection between neurodegeneration in the gut and subsequent dysmotility.

A transient entry of peripheral $\mathrm{T}$ cells, that recognize a mitochondria-derived antigen associated with intestinal inflammation, to the brain was found to drive SN dopamine axonal loss in Pink1-deficient mice (Matheoud et al., 2019). In contrast, we observed no CNS symptoms $\left(\mathrm{CD}^{+} \mathrm{T}\right.$ cell infiltrates, neuroinflammation or loss of dopaminergic neurons) in the $\alpha-\mathrm{syn}_{32-46} /$ HLA DRB1*15:01 mouse model. While surprising, this is consistent with reports that ENS symptoms appear decades prior to CNS symptoms in PD patients. The lack of CNS damage in the $\alpha$-syn $32-46$ / HLA DRB1*15:01 model suggests that a "second hit" may be required to target $\alpha$-synspecific T cells into the CNS, followed by neuroinflammation and loss of central dopaminergic neurons. This could be due to the transient, rather than chronic, exposure to the $\alpha$-syn epitope (two rounds of immunizations in mice in contrast to chronic exposure over decades in PD patients) or insufficient HLA-associated presentation of the $\alpha$-syn peptide in the brain. 
In conclusion, we have shown that $\alpha$-syn autoimmunity is sufficient to induce constipation and gut pathology with loss of dopaminergic neurons and drive prodromal symptoms of PD. The demonstration that a restrictive HLA allele in combination with an $\alpha$-syn-derived antigen leads to prodromal PD-like symptoms suggests that autoimmune responses to $\alpha$-syn-derived epitopes may play a fundamental role in driving the early stages of PD pathogenesis. A better understanding of the prodromal stages of PD would improve screening of at-risk patients that carry the specific HLA allele and report the onset of non-motor symptoms (e.g,. constipation). In addition, characterizing the early stages of PD may facilitate the design and target of early disease-modifying treatments that could prevent the progression of the pathology and development of motor dysfunction.

\section{ACKNOWLEDGEMENTS}

We thank Michael D. Gershon, Alcmene Chalazonitis-Green, and Wanda Setlik for guidance with enteric dissections, staining, and behavior experiments. We thank Ori Lieberman, Michael Post, Charlotte Wayne, Meagen Sykes, Ai Yamamoto, and Wassim Elyaman for support and suggestions. This research was funded in part by Aligning Science Across Parkinson's [\#0375] through the Michael J. Fox Foundation for Parkinson's Research (MJFF). For the purpose of open access, the authors have applied a CC BY public copyright license to all Author Accepted Manuscripts arising from this submission. D.S and E.K are also supported by NIH/NINDS (R01 NS095435) and the JPB Foundation. T.C., S.S., and D.A., are also supported by grants from the NIH/NIMH (R01 MH112849), NIH/NINDS (R01 NS107344), the National MS Society (RG1901-33218). D.A., and T.C., are partially supported by unrestricted gifts from the Newport 
Equities LLC and PANDAS Network to the Division of Cerebrovascular Diseases and Stroke, Department of Neurology, CUIMC.

\section{AUTHOR CONTRIBUTIONS}

F.G., D.A., A. S., and D.S., conceived the project; F.G., C.M., N.S., S.S., S.W.K., T.C., E.K. and D.A. performed the experiments and analyses, F.G., C.M., T.C. A.S., D.A., and D.S. wrote and edited the manuscript, and F.G. and C.M. prepared figures and figure legends.

\section{COMPETING INTERESTS}

The authors declare that the research was conducted without any commercial or financial relationships that can be construed as potential conflicts of interest.

\section{STAR METHODS}

\section{RESOURCE AVAILABILITY}

\section{Lead Contact}

Further information and requests for resources and reagents should be directed to and will be fulfilled by the lead contact, David Sulzer(ds43@cumc.columbia.edu).

\section{Materials availability}

This study did not generate new unique reagents.

\section{Data and code availability}

$\underline{\text { Data }}$

Microscopy and bulk RNA-seq data reported in this paper will be shared by the lead contact upon request. 


\section{Code}

This paper does not report original code.

\section{$\underline{\text { Section } 3}$}

Any additional information required to reanalyze the data reported in this paper is available from the lead contact upon request.

\section{EXPERIMENTAL MODEL AND SUBJECT DETAILS}

\section{Mice}

All experimental procedures were approved by the Institutional Animal Care and Use Committee (IACUC) at Columbia University Irving Medical Center (CUIMC). Generation of transgenic mice expressing the $H L A D R B 1 * 15: 01 \alpha$ and $\beta$ chains in the C57BL/6 background have been previously described (Krogman et al., 2017). Wild-type C57BL/6J were obtained from the Jackson Laboratory (Bar Harbor, ME). The HLA transgenic mice lacking mouse MHC-II were backcrossed to the C57BL/6J strain (Jackson Laboratory; Bar Harbor, ME) for more than 8 generations. All mice were bred within the barrier facility of CUIMC and group housed, fed regular chow. Both female and male mice were used in this study in equal numbers at the ages described in the text.

\section{METHOD DETAILS}

\section{Immunizations}

8- to 12 -week-old male and female mice were immunized subcutaneously with a $100 \mu$ emulsion of $100 \mu \mathrm{g}$ of $\alpha$-syn protein ( $\alpha$-syn; AnaSpec, Cat \#as-55555; Fremont, CA) or $\alpha$-syn32-46 (A\&A peptides; San Diego, CA) dissolved in PBS with Complete Freund Adjuvant (CFA) containing $200 \mu \mathrm{g}$ of M. tuberculosis H37Ra (BD Difco Adjuvant, Fisher Scientific, Cat \#DF0638-60-7; 
Waltham, MA). The day of immunization was designated as day 0 . Mice received a boost with the same immunization dose two weeks later. Mice received intravenous injections of $400 \mathrm{ng}$ of B. pertussis toxin (List Biological Laboratories, Cat \#181; Campbell, CA) 14- and 16-days postinitial immunization (day 0 and 2 post boost). Control animals received $B$. pertussis toxin and emulsion containing PBS/CFA without the protein or the $\alpha$-syn peptide. Mice were monitored for their weight, food and fluid intake and neurological deficits and their weights were recorded daily.

\section{Gut dissections}

Mice were perfused with PBS and segments of the ileum were collected in PBS. The contents were flushed out with PBS and the preparations were cut open along the mesenteric border. The flat tissue was stretched tautly and pinned flat on Sylgard (Sylgard ${ }^{\mathrm{TM}} 184$, Dow Corning, Cat \#2404019862; Midland, MI) with the mucosa surface facing up. Specimens were fixed for one hour at room temperature 4\% paraformaldehyde and washed three times with PBS for a total of $30 \mathrm{~min}$. The mucosa and submucosal plexus were removed from specimen by microdissection. Then, the mucosal was separated from the submucosal layer. The longitudinal muscles were microdissected from the specimen to reveal the myenteric plexus. The submucosal and myenteric plexuses were collected and store in PBS at $4^{\circ} \mathrm{C}$ until immunofluorescent staining.

\section{Intestinal flat mount immunofluorescence}

For immunofluorescence analysis, intestinal flat mounts were blocked and permeabilized for 1 hour at room temperature with 10\% normal donkey serum (Jackson Immunoresearch, Cat \#017000-121; West Grove, PA) and 1\% Triton-X in PBS. Intestinal flat mounts were then incubated overnight at room temperature with primary antibodies in $10 \%$ normal donkey serum, $1 \%$ Triton- 
$\mathrm{X}$ in PBS. Sections were stained with antibodies against tyrosine hydroxylase (TH) (1:500, Millipore-Sigma, Cat \# AB152; Burlington, MA) and CD3 (1:400, Bio-Rad Laboratories, Cat \#MCA2690; Hercules, CA), ANNA1 (1:32,000; kind gift by the Gershon laboratory (Margolis et al., 2016)), Iba1 (1:500, WAKO, Cat \# 019-19741; Richmond, VA), CD68 (1:1000, Abcam, Cat \# ab53444; Waltham, MA). Secondary antibodies with the appropriate conjugated fluorophores were purchased from Invitrogen. Images were acquired with an LSM700 confocal microscope and processed with Fiji software (ImageJ, NIH; Bethesda, MD).

\section{Total GI transit}

Carmine red, which cannot be absorbed from the lumen of the gut, was used to study total gastrointestinal (GI) transit time (Kimball et al., 2005). A solution of carmine red (300 $\mu$; 6\%; Sigma-Aldrich, Cat \#C1022; St Louis, MO) suspended in 0.5\% methylcellulose (Sigma-Aldrich, Cat \#M0512; St Louis, MO) was administered by gavage through a 21-gauge round-tip feeding needle. The time at which gavage took place was recorded as $T_{0}$. After gavage, fecal pellets were monitored at 10 min intervals for the presence of carmine red. Total GI transit time was considered as the interval between $T_{0}$ and the time of first observance of carmine red in the stool.

\section{Bulk RNA sequencing}

Ileum samples were incubated in TRIzol reagent (Thermo Fisher Scientific, Cat \#15596026;

Waltham, MA) and stored at $-80^{\circ} \mathrm{C}$. Total RNA was extracted and assessed for quality utilizing Agilent bioanalyzer for quantitation of RNA/DNA/protein (CUIMC Molecular Pathology Core). cDNA library preparation and RNA sequencing were performed by the CUIMC Genome Center. mRNAs were enriched from total RNA samples with poly-A pull-down, then processed with 
library construction using Illumina TruSeq chemistry. Libraries were then sequenced using Illumina NovaSeq6000 at CUIMC Genome Center. Samples were multiplexed in each lane, which yielded targeted number of paired-end 100bp reads for each sample. RTA (Illumina) for base calling and bcl2fastq2 (version 2.19) were used for converting BCL to fastq format, coupled with adaptor trimming. A pseudoalignment was performed to a kallisto index created from transcriptomes (GRCm38) using kallisto (0.44.0). Differentially expressed genes under various conditions were tested using DESeq2R packages designed to test differential expression between two experimental groups from RNA-seq counts data. Genes were considered differentially expressed if they had an adjusted p-value $<0.05$ and a $\log _{2}$ fold change below or above 0.5 . The differential expression was normalized for each gene.

\section{T cell depletions}

Mice were injected interperitoneally with $250 \mu \mathrm{g}$ of Ultra-LEAF Purified anti-mouse CD4 or Rat IgG2b isotype control antibodies (Biolegend, Cat \#100457 and Cat \#400644; San Diego, CA) 3and 1- days prior to immunization. After immunization, mice were injected with 250 ug of antibody weekly. Cell depletion was assessed via flow cytometry. For depletion of $\mathrm{CD}^{+} \mathrm{T}$ cells, mice were injected interperitoneally with $250 \mu \mathrm{g}$ of Ultra-LEAF Purified $\mathrm{CD}^{+}$or Rat IgG2b isotype control antibodies (Biolegend Cat \# 100746 and Cat \#400644; San Diego, CA) 2 days prior to immunization. After immunization, mice were injected with 250 ug of each antibody 9- and 19days post immunization, then cell depletion was determined via flow cytometry.

\section{QUANTIFICATION AND STATISTICAL ANALYSIS}


Fiji software (ImageJ, NIH; Bethesda, MD) was utilized for the quantitation of immunofluorescence images. Statistical analysis was performed using GraphPad Prism software version 8.0 (Graphpad Software Inc; San Diego, CA). Unpaired t test was used to compare the differences between two groups in studies. One-way and Two-way ANOVA followed by Bonferroni post hoc test was performed to compare the differences among groups. Differences between groups were presented as the mean \pm SEM or SD as noted in the figure legends. The sample size (n) for each experiment is indicated in figure legends and the Results section. All tests were two sided and $\mathrm{p}$ values $<0.05$ were considered to be statistically significant.

\section{KEY RESOURCES TABLE}

\begin{tabular}{|c|c|c|}
\hline REAGENT or RESOURCE & SOURCE & IDENTIFIER \\
\hline \multicolumn{3}{|l|}{ Antibodies } \\
\hline Anti-tyrosine hydroxylase antibody & Millipore & $\begin{array}{l}\text { Cat \#AB152, } \\
\text { RRID:AB_390204 }\end{array}$ \\
\hline Hamster anti mouse CD3 antibody & Bio-Rad & $\begin{array}{l}\text { Cat \#MCA2690, } \\
\text { RRID:AB } 905951\end{array}$ \\
\hline ANNA1 & Ghershon lab & $\begin{array}{l}\text { (Margolis et al., } \\
\text { 2016) }\end{array}$ \\
\hline Anti Ibal & $\begin{array}{l}\text { FUJIFILM Wako } \\
\text { Shibayagi }\end{array}$ & $\begin{array}{l}\text { Cat \#019-19741, } \\
\text { RRID:AB_839504 }\end{array}$ \\
\hline CD68 antibody [FA-11] & Abcam & $\begin{array}{l}\text { Cat \#ab53444, } \\
\text { RRID:AB_869007 }\end{array}$ \\
\hline Ultra-LEAFTM Purified anti-mouse CD4 Antibody & BioLegend & Cat \#100457 \\
\hline $\begin{array}{l}\text { Ultra-LEAFTM Purified Rat IgG2b isotype control } \\
\text { Antibody }\end{array}$ & BioLegend & Cat \#400644 \\
\hline Ultra-LEAFTM Purified anti-mouse CD8 Antibody & BioLegend & Cat \# 100746 \\
\hline Fixable viability dye eFluor 780 & eBiosciences & Cat \#65-0865 \\
\hline $\begin{array}{l}\text { Rat Anti-Mouse CD3 Molecular Complex } \\
\text { Monoclonal Antibody, PerCP-Cy5.5 Conjugated, } \\
\text { Clone 17A2 }\end{array}$ & BD Biosciences & $\begin{array}{l}\text { Cat\# 560527, } \\
\text { RRID:AB_172746 } \\
3\end{array}$ \\
\hline BV421 Rat anti-mouse CD4 & BD Biosciences & $\begin{array}{l}\text { Cat\# 562891, } \\
\text { RRID:AB_273787 } \\
0\end{array}$ \\
\hline
\end{tabular}




\begin{tabular}{|c|c|c|}
\hline $\begin{array}{l}\text { Brilliant Violet } 605(\mathrm{TM}) \text { anti-mouse CD8a } \\
\text { antibody }\end{array}$ & Biolegend & $\begin{array}{l}\text { Cat\# 100743, } \\
\text { RRID:AB_256135 } \\
2\end{array}$ \\
\hline APC Rat anti-mouse IFN-g & BD Biosciences & $\begin{array}{l}\text { Cat\# 554413, } \\
\text { RRID:AB_398551 }\end{array}$ \\
\hline $\begin{array}{l}\text { Rat Anti-IL-17 Monoclonal Antibody, } \\
\text { Phycoerythrin Conjugated, Clone TC11-18H10.1 }\end{array}$ & BD Biosciences & $\begin{array}{l}\text { Cat\# 559502, } \\
\text { RRID:AB_397256 }\end{array}$ \\
\hline $\begin{array}{l}\text { CD45 Monoclonal Antibody (30-F11), PerCP- } \\
\text { Cyanine5.5, eBioscience }\end{array}$ & $\begin{array}{l}\text { Thermo Fisher } \\
\text { Scientific }\end{array}$ & $\begin{array}{l}\text { Cat\# 45-0451-80, } \\
\text { RRID:AB_906233 }\end{array}$ \\
\hline Goat Anti-Mouse IgG H\&L (HRP) antibody & Abcam & $\begin{array}{l}\text { Cat\# ab205719, } \\
\text { RRID:AB_275504 } \\
9\end{array}$ \\
\hline \multicolumn{3}{|l|}{ Chemicals, peptides, and recombinant proteins } \\
\hline $\begin{array}{l}\text { EndoClear }{ }^{\mathrm{TM}} \text { human recombinant a-Synuclein } \\
\text { protein }\end{array}$ & AnaSpec & Cat \#as-55555 \\
\hline -syn $32-46$ (KTKEGVLYVGSKTKE) & A\&A peptides & Per request \\
\hline $\begin{array}{l}\text { Pertussis Toxin from B. pertussis, Lyophilized } \\
\text { (Salt-Free) }\end{array}$ & List Labs & Cat \#181 \\
\hline $\begin{array}{l}\text { Complete Freund Adjuvant (CFA) containing } \\
200 \mu \mathrm{g} \text { of } M . \text { tuberculosis } \mathrm{H} 37 \mathrm{Ra}\end{array}$ & $\begin{array}{l}\text { BD Difco Adjuvant, } \\
\text { Fisher Scientific }\end{array}$ & Cat \#DF0638-60-7 \\
\hline Carmine (powder) & Millipore- Sigma & Cat \#C1022 \\
\hline Concanavalin A & Millipore-Sigma & Cat \#C2010 \\
\hline \multicolumn{3}{|l|}{ Critical commercial assays } \\
\hline Mouse IFN-gamma DuoSet ELISA & R\&D systems & Cat \#DY485 \\
\hline Mouse IL-17A DuoSet ELISA & R\&D systems & Cat \#DY421 \\
\hline \multicolumn{3}{|l|}{ Experimental models: Organisms/strains } \\
\hline $\begin{array}{l}\text { Mouse: HLA DRB1*15:01 in C57BL/6J } \\
\text { background }\end{array}$ & $\begin{array}{l}\text { This paper, Chella } \\
\text { David laboratory } \\
\text { (Mayo Clinic) }\end{array}$ & $\begin{array}{l}\text { (Krogman et al., } \\
\text { 2017) }\end{array}$ \\
\hline Mouse: C57BL/6J & $\begin{array}{l}\text { The Jackson } \\
\text { Laboratory }\end{array}$ & Strain $\# 000664$ \\
\hline \multicolumn{3}{|l|}{ Oligonucleotides } \\
\hline $\begin{array}{l}\text { Primers for hygromycin control. Forward: } \\
\text { ctgatcgaaaagttcgacagc, Reverse: } \\
\text { gtattgaccgattccttccg }\end{array}$ & IDT & $\mathrm{N} / \mathrm{A}$ \\
\hline $\begin{array}{l}\text { Primers for DRalpha. Forward: ccgagctctactgact, } \\
\text { Reverse: gacttacttcagtttgtgg }\end{array}$ & IDT & $\mathrm{N} / \mathrm{A}$ \\
\hline $\begin{array}{l}\text { Primers for DR2beta. Forward: } \\
\text { tcgccgctgcactgtgaag, Reverse: tcctgtggcagcctaagag }\end{array}$ & IDT & $\mathrm{N} / \mathrm{A}$ \\
\hline \multicolumn{3}{|l|}{ Software and algorithms } \\
\hline Fiji & ImageJ & $\begin{array}{l}\text { https://imagej.net/s } \\
\text { oftware/fiji/ }\end{array}$ \\
\hline
\end{tabular}


bioRxiv preprint doi: https://doi.org/10.1101/2022.02.03.479014; this version posted February 5, 2022. The copyright holder for this preprint (which was not certified by peer review) is the author/funder, who has granted bioRxiv a license to display the preprint in perpetuity. It is made available under aCC-BY-NC-ND 4.0 International license.

\begin{tabular}{|l|l|l|}
\hline Prism v9.0 & GraphPad & $\begin{array}{l}\text { https://www.graph } \\
\text { pad.com/scientific- } \\
\text { software/prism/ }\end{array}$ \\
\hline DESeq2R & R package & $\begin{array}{l}\mathrm{https} / / \text { bioconducto } \\
\text { r.org/packages/rele } \\
\text { ase/bioc/html/DES } \\
\text { eq2.html }\end{array}$ \\
\hline
\end{tabular}




\section{REFERENCES}

Aldecoa, I., Navarro-Otano, J., Stefanova, N., Sprenger, F.S., Seppi, K., Poewe, W., Cuatrecasas, M., Valldeoriola, F., Gelpi, E., and Tolosa, E. (2015). Alpha-synuclein immunoreactivity patterns in the enteric nervous system. Neurosci Lett 602, 145-149.

Annerino, D.M., Arshad, S., Taylor, G.M., Adler, C.H., Beach, T.G., and Greene, J.G. (2012). Parkinson's disease is not associated with gastrointestinal myenteric ganglion neuron loss. Acta Neuropathol 124, 665-680.

Appel-Cresswell, S., Vilarino-Guell, C., Encarnacion, M., Sherman, H., Yu, I., Shah, B., Weir, D., Thompson, C., Szu-Tu, C., Trinh, J., et al. (2013). Alpha-synuclein p.H50Q, a novel pathogenic mutation for Parkinson's disease. Mov Disord 28, 811-813.

Beach, T.G., Adler, C.H., Lue, L., Sue, L.I., Bachalakuri, J., Henry-Watson, J., Sasse, J., Boyer, S., Shirohi, S., Brooks, R., et al. (2009). Unified staging system for Lewy body disorders: correlation with nigrostriatal degeneration, cognitive impairment and motor dysfunction. Acta Neuropathol 117, 613-634.

Boschetti, E., Malagelada, C., Accarino, A., Malagelada, J.R., Cogliandro, R.F., Gori, A., Bonora, E., Giancola, F., Bianco, F., Tugnoli, V., et al. (2019). Enteric neuron density correlates with clinical features of severe gut dysmotility. Am J Physiol Gastrointest Liver Physiol 317 , G793-G801.

Braak, H., Del Tredici, K., Rub, U., de Vos, R.A., Jansen Steur, E.N., and Braak, E. (2003). Staging of brain pathology related to sporadic Parkinson's disease. Neurobiology of aging 24, 197-211.

Brochard, V., Combadiere, B., Prigent, A., Laouar, Y., Perrin, A., Beray-Berthat, V., Bonduelle, O., Alvarez-Fischer, D., Callebert, J., Launay, J.M., et al. (2009). Infiltration of CD4+ lymphocytes into the brain contributes to neurodegeneration in a mouse model of Parkinson disease. J Clin Invest 119, 182-192.

Corbille, A.G., Coron, E., Neunlist, M., Derkinderen, P., and Lebouvier, T. (2014). Appraisal of the dopaminergic and noradrenergic innervation of the submucosal plexus in PD. J Parkinsons Dis 4, 571-576.

Cossais, F., Schaeffer, E., Heinzel, S., Zimmermann, J., Niesler, B., Roth, R., Rappold, G., Scharf, A., Zorenkov, D., Lange, C., et al. (2021). Expression Profiling of Rectal Biopsies Suggests Altered Enteric Neuropathological Traits in Parkinson's Disease Patients. J Parkinsons Dis 11, 171-176.

Coulombe, J.N., and Bronner-Fraser, M. (1986). Cholinergic neurones acquire adrenergic neurotransmitters when transplanted into an embryo. Nature 324, 569-572. 
Devos, D., Lebouvier, T., Lardeux, B., Biraud, M., Rouaud, T., Pouclet, H., Coron, E., Bruley des Varannes, S., Naveilhan, P., Nguyen, J.M., et al. (2013). Colonic inflammation in Parkinson's disease. Neurobiology of disease 50, 42-48.

Drossman, D.A. (2006). The functional gastrointestinal disorders and the Rome III process. Gastroenterology 130, 1377-1390.

Fahn, S., and Sulzer, D. (2004). Neurodegeneration and neuroprotection in Parkinson disease. NeuroRx 1, 139-154.

Fasano, A., Visanji, N.P., Liu, L.W., Lang, A.E., and Pfeiffer, R.F. (2015). Gastrointestinal dysfunction in Parkinson's disease. Lancet Neurol 14, 625-639.

Finn, T.P., Jones, R.E., Rich, C., Dahan, R., Link, J., David, C.S., Chou, Y.K., Offner, H., and Vandenbark, A.A. (2004). HLA-DRB1*1501 risk association in multiple sclerosis may not be related to presentation of myelin epitopes. J Neurosci Res 78, 100-114.

Fujiwara, H., Hasegawa, M., Dohmae, N., Kawashima, A., Masliah, E., Goldberg, M.S., Shen, J., Takio, K., and Iwatsubo, T. (2002). alpha-Synuclein is phosphorylated in synucleinopathy lesions. Nat Cell Biol 4, 160-164.

Garretti, F., Agalliu, D., Lindestam Arlehamn, C.S., Sette, A., and Sulzer, D. (2019). Autoimmunity in Parkinson's Disease: The Role of alpha-Synuclein-Specific T Cells. Front Immunol 10, 303.

Hamza, T.H., Zabetian, C.P., Tenesa, A., Laederach, A., Montimurro, J., Yearout, D., Kay, D.M., Doheny, K.F., Paschall, J., Pugh, E., et al. (2010). Common genetic variation in the HLA region is associated with late-onset sporadic Parkinson's disease. Nat Genet 42, 781-785.

Harvey, D.C., Lacan, G., Tanious, S.P., and Melega, W.P. (2000). Recovery from methamphetamine induced long-term nigrostriatal dopaminergic deficits without substantia nigra cell loss. Brain Res 871, 259-270.

Heinzel, S., Berg, D., Gasser, T., Chen, H., Yao, C., Postuma, R.B., and Disease, M.D.S.T.F.o.t.D.o.P.s. (2019). Update of the MDS research criteria for prodromal Parkinson's disease. Mov Disord 34, 1464-1470.

Hill-Burns, E.M., Factor, S.A., Zabetian, C.P., Thomson, G., and Payami, H. (2011). Evidence for more than one Parkinson's disease-associated variant within the HLA region. PLoS One 6 , e27109. 
Hotchkiss, A.J., and Gibb, J.W. (1980). Long-term effects of multiple doses of methamphetamine on tryptophan hydroxylase and tyrosine hydroxylase activity in rat brain. $\mathrm{J}$ Pharmacol Exp Ther 214, 257-262.

Kannarkat, G.T., Cook, D.A., Lee, J.K., Chang, J., Chung, J., Sandy, E., Paul, K.C., Ritz, B., Bronstein, J., Factor, S.A., et al. (2015). Common Genetic Variant Association with Altered HLA Expression, Synergy with Pyrethroid Exposure, and Risk for Parkinson's Disease: An Observational and Case-Control Study. NPJ Parkinsons Dis 1.

Khare, M., Mangalam, A., Rodriguez, M., and David, C.S. (2005). HLA DR and DQ interaction in myelin oligodendrocyte glycoprotein-induced experimental autoimmune encephalomyelitis in HLA class II transgenic mice. J Neuroimmunol 169, 1-12.

Khoo, T.K., Yarnall, A.J., Duncan, G.W., Coleman, S., O'Brien, J.T., Brooks, D.J., Barker, R.A., and Burn, D.J. (2013). The spectrum of nonmotor symptoms in early Parkinson disease.

Neurology 80, 276-281.

Ki, C.S., Stavrou, E.F., Davanos, N., Lee, W.Y., Chung, E.J., Kim, J.Y., and Athanassiadou, A. (2007). The Ala53Thr mutation in the alpha-synuclein gene in a Korean family with Parkinson disease. Clin Genet 71, 471-473.

Kimball, E.S., Palmer, J.M., D'Andrea, M.R., Hornby, P.J., and Wade, P.R. (2005). Acute colitis induction by oil of mustard results in later development of an IBS-like accelerated upper GI transit in mice. Am J Physiol Gastrointest Liver Physiol 288, G1266-1273.

Krogman, A., Tilahun, A., David, C.S., Chowdhary, V.R., Alexander, M.P., and Rajagopalan, G. (2017). HLA-DR polymorphisms influence in vivo responses to staphylococcal toxic shock syndrome toxin-1 in a transgenic mouse model. HLA 89, 20-28.

Kruger, R., Kuhn, W., Muller, T., Woitalla, D., Graeber, M., Kosel, S., Przuntek, H., Epplen, J.T., Schols, L., and Riess, O. (1998). Ala30Pro mutation in the gene encoding alpha-synuclein in Parkinson's disease. Nat Genet 18, 106-108.

Kulkarni, S., Micci, M.A., Leser, J., Shin, C., Tang, S.C., Fu, Y.Y., Liu, L., Li, Q., Saha, M., Li, C., et al. (2017). Adult enteric nervous system in health is maintained by a dynamic balance between neuronal apoptosis and neurogenesis. Proc Natl Acad Sci U S A 114, E3709-E3718.

Lebouvier, T., Neunlist, M., Bruley des Varannes, S., Coron, E., Drouard, A., N'Guyen, J.M., Chaumette, T., Tasselli, M., Paillusson, S., Flamand, M., et al. (2010). Colonic biopsies to assess the neuropathology of Parkinson's disease and its relationship with symptoms. PLoS One 5, e12728. 
Lesage, S., Anheim, M., Letournel, F., Bousset, L., Honore, A., Rozas, N., Pieri, L., Madiona, K., Durr, A., Melki, R., et al. (2013). G51D alpha-synuclein mutation causes a novel parkinsonian-pyramidal syndrome. Ann Neurol 73, 459-471.

Li, Z.S., Pham, T.D., Tamir, H., Chen, J.J., and Gershon, M.D. (2004). Enteric dopaminergic neurons: definition, developmental lineage, and effects of extrinsic denervation. J Neurosci 24 , 1330-1339.

Li, Z.S., Schmauss, C., Cuenca, A., Ratcliffe, E., and Gershon, M.D. (2006). Physiological modulation of intestinal motility by enteric dopaminergic neurons and the D2 receptor: analysis of dopamine receptor expression, location, development, and function in wild-type and knockout mice. J Neurosci 26, 2798-2807.

Lindestam Arlehamn, C.S., Dhanwani, R., Pham, J., Kuan, R., Frazier, A., Rezende Dutra, J., Phillips, E., Mallal, S., Roederer, M., Marder, K.S., et al. (2020). alpha-Synuclein-specific T cell reactivity is associated with preclinical and early Parkinson's disease. Nat Commun 11, 1875.

Liu, B., Fang, F., Pedersen, N.L., Tillander, A., Ludvigsson, J.F., Ekbom, A., Svenningsson, P., Chen, H., and Wirdefeldt, K. (2017). Vagotomy and Parkinson disease: A Swedish registerbased matched-cohort study. Neurology 88, 1996-2002.

Liu, H., Koros, C., Strohaker, T., Schulte, C., Bozi, M., Varvaresos, S., Ibanez de Opakua, A., Simitsi, A.M., Bougea, A., Voumvourakis, K., et al. (2021). A Novel SNCA A30G Mutation Causes Familial Parkinson's Disease. Mov Disord 36, 1624-1633.

Margolis, K.G., Li, Z., Stevanovic, K., Saurman, V., Israelyan, N., Anderson, G.M., Snyder, I., Veenstra-VanderWeele, J., Blakely, R.D., and Gershon, M.D. (2016). Serotonin transporter variant drives preventable gastrointestinal abnormalities in development and function. J Clin Invest 126, 2221-2235.

Matheoud, D., Cannon, T., Voisin, A., Penttinen, A.M., Ramet, L., Fahmy, A.M., Ducrot, C., Laplante, A., Bourque, M.J., Zhu, L., et al. (2019). Intestinal infection triggers Parkinson's disease-like symptoms in Pink1(-/-) mice. Nature 571, 565-569.

Metzger, J.M., and Emborg, M.E. (2019). Autonomic dysfunction in Parkinson disease and animal models. Clin Auton Res 29, 397-414.

Mrabet, S., Ben Ali, N., Achouri, A., Dabbeche, R., Najjar, T., Haouet, S., and Belal, S. (2016). Gastrointestinal Dysfunction and Neuropathologic Correlations in Parkinson Disease. J Clin Gastroenterol 50, e85-90.

Oh, J., Vidal-Jordana, A., and Montalban, X. (2018). Multiple sclerosis: clinical aspects. Curr Opin Neurol 31, 752-759. 
Park, S., Kim, J., Chun, J., Han, K., Soh, H., Kang, E.A., Lee, H.J., Im, J.P., and Kim, J.S. (2019). Patients with Inflammatory Bowel Disease Are at an Increased Risk of Parkinson's Disease: A South Korean Nationwide Population-Based Study. J Clin Med 8.

Pasanen, P., Myllykangas, L., Siitonen, M., Raunio, A., Kaakkola, S., Lyytinen, J., Tienari, P.J., Poyhonen, M., and Paetau, A. (2014). Novel alpha-synuclein mutation A53E associated with atypical multiple system atrophy and Parkinson's disease-type pathology. Neurobiology of aging 35,2180 e2181-2185.

Peter, I., Dubinsky, M., Bressman, S., Park, A., Lu, C., Chen, N., and Wang, A. (2018). AntiTumor Necrosis Factor Therapy and Incidence of Parkinson Disease Among Patients With Inflammatory Bowel Disease. JAMA Neurol 75, 939-946.

Pochard, C., Leclair-Visonneau, L., Coron, E., Neunlist, M., Rolli-Derkinderen, M., and Derkinderen, P. (2018). Cyclooxygenase 2 is upregulated in the gastrointestinal tract in Parkinson's disease. Mov Disord 33, 493-494.

Polymeropoulos, M.H., Lavedan, C., Leroy, E., Ide, S.E., Dehejia, A., Dutra, A., Pike, B., Root, H., Rubenstein, J., Boyer, R., et al. (1997). Mutation in the alpha-synuclein gene identified in families with Parkinson's disease. Science 276, 2045-2047.

Punsoni, M., Friedman, J.H., Resnick, M., Donahue, J.E., Yang, D.F., and Stopa, E.G. (2019). Enteric Pathologic Manifestations of Alpha-Synucleinopathies. Appl Immunohistochem Mol Morphol 27, 543-548.

Qin, X.Y., Zhang, S.P., Cao, C., Loh, Y.P., and Cheng, Y. (2016). Aberrations in Peripheral Inflammatory Cytokine Levels in Parkinson Disease: A Systematic Review and Meta-analysis. JAMA Neurol 73, 1316-1324.

Rao, M., and Gershon, M.D. (2016). The bowel and beyond: the enteric nervous system in neurological disorders. Nat Rev Gastroenterol Hepatol 13, 517-528.

Sommer, A., Maxreiter, F., Krach, F., Fadler, T., Grosch, J., Maroni, M., Graef, D., Eberhardt, E., Riemenschneider, M.J., Yeo, G.W., et al. (2018). Th17 Lymphocytes Induce Neuronal Cell Death in a Human iPSC-Based Model of Parkinson's Disease. Cell stem cell 23, 123-131 e126.

Soriano, M.A., Justicia, C., Ferrer, I., Rodriguez-Farre, E., and Planas, A.M. (1997). Striatal infarction in the rat causes a transient reduction of tyrosine hydroxylase immunoreactivity in the ipsilateral substantia nigra. Neurobiology of disease 4, 376-385.

Stokholm, M.G., Danielsen, E.H., Hamilton-Dutoit, S.J., and Borghammer, P. (2016). Pathological alpha-synuclein in gastrointestinal tissues from prodromal Parkinson disease patients. Ann Neurol 79, 940-949. 
Sulzer, D., Alcalay, R.N., Garretti, F., Cote, L., Kanter, E., Agin-Liebes, J., Liong, C., McMurtrey, C., Hildebrand, W.H., Mao, X., et al. (2017). T cells from patients with Parkinson's disease recognize alpha-synuclein peptides. Nature 546, 656-661.

Svensson, E., Horvath-Puho, E., Thomsen, R.W., Djurhuus, J.C., Pedersen, L., Borghammer, P., and Sorensen, H.T. (2015). Vagotomy and subsequent risk of Parkinson's disease. Ann Neurol $78,522-529$.

Tysnes, O.B., Kenborg, L., Herlofson, K., Steding-Jessen, M., Horn, A., Olsen, J.H., and Reichmann, H. (2015). Does vagotomy reduce the risk of Parkinson's disease? Ann Neurol 78, 1011-1012.

Williams, G.P., Schonhoff, A.M., Jurkuvenaite, A., Gallups, N.J., Standaert, D.G., and Harms, A.S. (2021). CD4 T cells mediate brain inflammation and neurodegeneration in a mouse model of Parkinson's disease. Brain 144, 2047-2059.

Wolinsky, E., and Patterson, P.H. (1983). Tyrosine hydroxylase activity decreases with induction of cholinergic properties in cultured sympathetic neurons. J Neurosci 3, 1495-1500.

Yang, J., Sundrud, M.S., Skepner, J., and Yamagata, T. (2014). Targeting Th17 cells in autoimmune diseases. Trends Pharmacol Sci 35, 493-500.

Yoo, B.B., and Mazmanian, S.K. (2017). The Enteric Network: Interactions between the Immune and Nervous Systems of the Gut. Immunity 46, 910-926.

Yoshino, H., Hirano, M., Stoessl, A.J., Imamichi, Y., Ikeda, A., Li, Y., Funayama, M., Yamada, I., Nakamura, Y., Sossi, V., et al. (2017). Homozygous alpha-synuclein p.A53V in familial Parkinson's disease. Neurobiology of aging 57, 248 e247-248 e212.

Zarranz, J.J., Alegre, J., Gomez-Esteban, J.C., Lezcano, E., Ros, R., Ampuero, I., Vidal, L., Hoenicka, J., Rodriguez, O., Atares, B., et al. (2004). The new mutation, E46K, of alphasynuclein causes Parkinson and Lewy body dementia. Ann Neurol 55, 164-173. 


\section{FIGURE LEGENDS}

\section{Figure 1. $\alpha-S_{32}$ 32-46 peptide immunizations induce weight loss in HLA DRB1*15:01, but not}

WT, mice. (A) A schematic diagram of the experimental design. WT and HLA mice were immunized with PBS/CFA, $\alpha$-syn protein/CFA or $\alpha-$ syn $_{32-46}$ peptide/CFA and received a boost after two weeks. At 14 and 16 DPI, an intravenous injection of B. pertussis toxin (Ptx) was administered. Mice were monitored daily for signs of illness and change in weight. (B) Pie charts show the fraction of WT (top) - and HLA (bottom) - immunized mice that were healthy (light purple), became ill (dark purple) or died (gray). (C, D) Plots of percentage weight change from the initial weight (0 DPI) for WT (C) and HLA (D) mice immunized with either CFA (black circles), $\alpha$-syn protein (blue squares) or $\alpha$-syn $32-46$ peptide (green triangles). The red dashed lines indicate the time when mice received an immunization boost and PTx injections at 14 and 16 DPI, respectively. (E) Graph depicting the percentage of weight loss for CFA and sick $\alpha-$ syn $_{32-46^{-}}$ immunized HLA mice. The data in $(\mathbf{E})$ were analyzed using a mixed-effect ANOVA for repeated measurements followed by Bonferroni post-hoc correction; * $\mathrm{p}<0.05$; WT/CFA ( $\mathrm{n}=23$ mice), WT/ $\alpha$-syn protein ( $\mathrm{n}=13$ mice), WT/ $\alpha$-syn $32-46$ peptide ( $\mathrm{n}=25$ mice), HLA/CFA ( $\mathrm{n}=24$ mice), HLA/ $\alpha$-syn protein $(n=12$ mice), HLA/ $\alpha$-syn $32-46$ peptide ( $\mathrm{n}=35$ mice).

Figure 2. Total GI transit time is delayed in $\alpha-$ syn $_{32-46}$ immunized HLA mice. (A, B) Schematic diagrams of the experimental design for immunization and gastrointestinal (GI) transit time. Mice were gavaged with unabsorbable carmine red mixture. The time from the oral gavage to the release of a red fecal pellet was recorded as the total gastrointestinal (GI) transit time. The total GI time was measured at 21, 25, and 35 DPI. (C, D) Bar graphs depicting the total GI transit time at 21 
DPI for either all (C) or sick (D) CFA (black) and $\alpha$-syn $32-46$ (green)- immunized HLA mice. (E,

F) Bar graphs depicting the total GI transit time of CFA (black) and $\alpha$-syn $32-46$ (green)-immunized HLA mice at 25 (E) and 35 (F) DPI. (G, H) Correlation graphs between peak weight loss and total GI transit time of CFA $(\mathbf{G})$ and $\alpha$-syn $32-46(\mathbf{H})$-immunized mice. Dark purple circles represent sick and light purple circles represent healthy mice. (I) Bar graphs of the total GI transit time of WT (dark bars) and HLA (light bars) immunized with CFA only (black circles) or $\alpha$-syn $32-46$ (green circles). Only sick $\alpha$-syn $32-46$-immunized HLA mice are shown. Data were analyzed by MannWhitney test $(\mathbf{C}, \mathbf{D})$, Pearson correlation $(\mathbf{G}, \mathbf{H})$ and two-way ANOVA (I); * p $<0.05$, $* * * * \mathrm{p}<0.0001$. Bar graphs represent the mean and SEM. Each symbol represents data from one animal. WT/CFA only $n=13$ mice, WT/a-syn $32-46 n=14$ mice, HLA/CFA only $n=19$ mice, HLA/asyn $_{32-46} \mathrm{n}=21$ mice. WT: 2 independent experiments, HLA: 4 independent experiments.

Figure 3. $\alpha-S_{32-46}$ immunizations induce intestinal inflammation and dopaminergic neuron loss in HLA DRB1*15:01 mice. (A, B) Schematic diagram of the experimental design and the myenteric and submucosal plexuses of the ileum used for analysis. (C-F) Representative images of the myenteric and submucosal plexuses stained for DAPI (blue), TH (green), Iba1 (red), CD68 (white). Thick white arrows indicate macrophages. (G-J) Representative images of the myenteric and submucosal plexuses stained for DAPI (blue), TH (green), and ANNA1 (red). Thin white arrows indicate cell bodies of dopaminergic neurons; white arrowheads indicate dopaminergic neuronal processes. $(\mathbf{K}, \mathbf{L})$ Dotted bar graphs of the number of Iba $1^{+}$cells $/ 100 \mathrm{~mm}^{2}$ in myenteric (K) and submucosal (L) plexuses of PBS/CFA (black circles) and $\alpha$-syn $32-46 /$ CFA (green circles)immunized mice. (M-R) Dotted bar graphs of ANNA1 ${ }^{+}(\mathbf{M})$ and $\mathrm{TH}^{+}(\mathbf{N})$ neurons per $\mathrm{mm}^{2}$ in the 
myenteric plexus, $\mathrm{ANNA1}^{+}(\mathbf{O})$, or $\mathrm{TH}^{+}(\mathbf{P})$ neurons per $\mathrm{mm}^{2}$, area covered $(\mathbf{Q})$ and mean fluorescence intensity (MFI) (R) of the TH signal in the submucosal plexus of CFA (black circles) and $\alpha$-syn $32-46$ (green circles)-immunized HLA mice. Bar graphs show the mean and error bars the SEM. Data were analyzed by the Mann-Whitney test $(\mathbf{K}-\mathbf{R}) .{ }^{*} \mathrm{p}<0.05,{ }^{* *} \mathrm{p}<0.01$. HLA/CFA $\mathrm{n}=10$ mice; HLA/ $\alpha-\operatorname{syn}_{32-46} \mathrm{n}=14$ mice; data collected from 4 independent experiments. Scale bars $(\mathbf{C}$ F) $=50 \mu \mathrm{m} .(\mathbf{G}-\mathbf{J})=75 \mu \mathrm{m}$.

Figure 4. Dopaminergic neuron loss begins 18 days post-immunization in $\alpha$-syn $32-46$ immunized HLA DRB1*15:01 mice. (A, B) Schematic diagram of the experimental design (A) and the myenteric and submucosal plexuses of the ileum $(\mathbf{B})$ used for analysis. HLA DRB1*15:01 mice were immunized with PBS/CFA or $\alpha-\operatorname{syn}_{32-46} / \mathrm{CFA}$ and received a boost after two weeks. At 14 and 16 DPI, B. pertussis toxin (Ptx) was administered intravenously. At 18 and 42 DPI, the ileum was dissected out for analysis. (C-F) Representative images of the myenteric and submucosal plexuses at 18 DPI stained for DAPI (blue), TH (green), and Iba1 (red) CD68 (white). $(\mathbf{G}, \mathbf{H})$ Dotted bar graphs depicting the number of $\mathrm{Iba}^{+}{ }^{+}$cells normalized to CFA in the myenteric (G) and submucosal (H) plexuses of CFA (black circles) and $\alpha$-syn $32-46$ (green circles)-immunized mice at 18 DPI. (I, J) Dotted bar graphs of $\mathrm{TH}^{+}$cells (normalized to CFA) in the myenteric (I) and submucosal (J) plexuses of CFA (black circles) and $\alpha$-syn $32-46$ (green circles)-immunized mice at 18 DPI. (K, L) Dotted bar graphs of the area (K) and mean fluorescence intensity (MFI) (L) of TH signal in the submucosal plexus of CFA (black circles) and $\alpha$-syn $32-46$ (green circles)immunized mice at 18 DPI. (M-P) Representative images of the myenteric and submucosal plexuses at 42 DPI stained for DAPI (blue), TH (green), and Ibal (red) CD68 (white). (Q-V) 
Dotted bar graphs of IBA $1^{+}$cells normalized to CFA in the myenteric (Q) and submucosal plexuses

(R), $\mathrm{TH}^{+}$cells normalized to CFA in the myenteric (S) and submucosal (T) plexuses, the area (U) and mean fluorescence intensity (MFI) (V) of TH signal in the submucosal plexus of CFA (black circles) and $\alpha-$ syn $_{32-46}$ (green circles)-immunized mice at 42 DPI. Dotted bar graphs show the mean and error bars the SEM. Each symbol represents data collected from a mouse. Data were analyzed by a two-tailed Student T-test $(\mathbf{G}-\mathbf{V}) .{ }^{*} \mathrm{p}<0.05,{ }^{*} \mathrm{p}<0.01 .18$ DPI: HLA/CFA $\mathrm{n}=5$ mice, HLA/ $\alpha-$ $\operatorname{syn}_{32-46} \mathrm{n}=5$ mice; 42 DPI: HLA/CFA $n=6$ mice, HLA/ $\alpha-\operatorname{syn}_{32-46} \mathrm{n}=6$ mice (data were collected from one experiment). Scale bars $=50 \mathrm{~mm}$.

Figure 5. Upregulation of genes associated with the innate and adaptive immune responses in the ileums of $\alpha$-syn 32-46 immunized HLA mice. (A) A volcano plot of differentially expressed genes from the ileums of $\alpha-\mathrm{syn}_{32-46}$ versus PBS - immunized HLA mice at 21 DPI. Significantly down-regulated (blue) and up-regulated (red) genes of interest are plotted by fold change on the $\mathrm{x}$-axis and the adjusted $\mathrm{p}$-value on the $\mathrm{y}$-axis. Red lines indicate adjusted $\mathrm{p}$ values $\left(\mathrm{p}_{\mathrm{adj}}\right) \leq 0.05$ and $\mid \log _{2}$ fold change $\mid \geq 0.5$ which were used to identify statistically significant, differentiallyexpressed genes. Genes of interest are highlighted in green. (B) GO enrichment bar graph depicting five functional categories of upregulated genes from the ileum of $\alpha$-syn $32-46$ immunized HLA mice at $21 \mathrm{DPI}$. Red diamonds indicate the number of genes represented by the GO term, and gray bars indicate $-\log _{2}$ (FDR) values. GO terms are considered significant with a false discovery rate (FDR) $<0.05$. (C-F) Volcano plots of upregulated genes associated with the GO terms: (C) innate immune response (GO: 0045087), (D) response to cytokine (GO: 0034097), (E) response to interferon-b (GO: 0035456), (F) lymphocyte and humoral immunity (GO: 0002449; GO: 
0002455). Genes that are significantly down or up-regulated are represented in blue and red, respectively. Genes of interest are highlighted in green.

\section{Figure 6. $\mathrm{CD4}^{+} \mathrm{T}$ cell depletion partially rescues neuronal loss in $\alpha-$ syn $_{32-46}$ immunized HLA}

mice. (A) A schematic diagram of the experimental design. HLA mice were immunized with $\alpha$ $\operatorname{syn}_{32-46} / \mathrm{CFA}$ and received a boost after two weeks. At 14 and 16 DPI, B. pertussis toxin (Ptx) was administered intravenously. Mice received $\alpha$-CD4 or isotype control antibodies intraperitoneally at -3 and -1 DPI (white arrowheads) and then at weekly intervals. Mice received $\alpha$-CD8 antibodies intraperitoneally at -2 DPI (white arrowheads) and then at 10-day intervals. At 28 DPI, the ileum was dissected out for analysis. (B) Graph showing the levels of $\mathrm{CD}^{+}$or $\mathrm{CD}^{+} \mathrm{T}$ cells as $\%$ of $\mathrm{CD}^{+} 5^{+}$cells at three distinct DPIs in $\alpha-\mathrm{syn}_{32-46}$-immunized HLA mice for each treatment: $\alpha$-CD4 (red), $\alpha$-CD8 (teal), or isotype control (gray). (C) Kaplan Meier curve depicting the probability of survival and (D) pie charts displaying the proportion of $\alpha$-CD4 (red)-, $\alpha-C D 8$ (teal)-, or isotype control (gray)-treated $\alpha$-syn32-46-immunized HLA mice that remained healthy (light purple), became ill (dark purple) or died (gray). (E) Graph depicting the changes in weight reported as percent of change from initial weight (0 DPI) of $\alpha$-CD4 (red)-, $\alpha-C D 8$ (teal)-, or isotype control (gray)-treated $\alpha$-syn $32-46$-immunized HLA mice. (F-L) Bar graphs depicting the total GI transit time $(\mathbf{F})$, number of dopaminergic neurons $(\mathbf{G}, \mathbf{H})$, all neurons $(\mathbf{I}, \mathbf{J})$, and macrophages $(\mathbf{K}, \mathbf{L})$ in the myenteric (top panels) and submucosal (bottom panels) plexuses of $\alpha$-CD4 (red)-, $\alpha-C D 8$ (teal)-, or isotype control (gray)-treated $\alpha$-syn $32-46$-immunized HLA mice. Data analyzed by repeated-measure ANOVA $(\mathbf{B}, \mathbf{C})$ and two-way ANOVA $(\mathbf{G}-\mathbf{L})$. Bar graphs depict the mean and error bars the SEM. Each symbol in the bar graphs represents the data collected from one mouse. 
$* \mathrm{p}<0.05, * * * \mathrm{p}<0.001$. Isotype control $\mathrm{n}=8$ mice, $\alpha-\mathrm{CD} 4 \mathrm{n}=10$ mice $\alpha-\operatorname{CD} 8 \mathrm{n}=8$, data collected from 3 independent experiments.

Figure 7. The role of $\alpha$-syn-specific $\mathbf{T}$ cells in PD pathogenesis. $\alpha$-Syn-specific $\mathrm{T}$ cells have been identified in PD patients expressing HLA DRB1*15:01. Humanized mice lacking MHCII-/and expressing HLA DRB1*15:01 that are immunized with the $\alpha$-syn $32-46$ peptide may produce $\alpha$ syn-specific $\mathrm{T}$ cells in the periphery that leave the circulation to go to target organs. We postulate that the gut is one such organ, since HLA mice display enteric inflammation and neurodegeneration in the submucosal plexus. However, there is no inflammation and $\mathrm{T}$ cell infiltration into the brains of $\alpha$-syn $32-46$-immunized HLA mice, suggesting that additional factors are required to induce the CNS neuropathology and behavioral phenotypes characteristic of PD. 
A

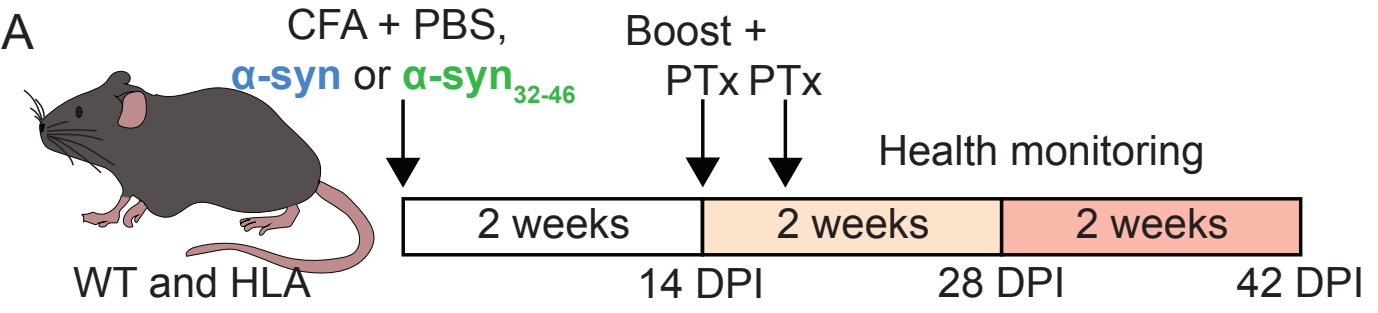

C

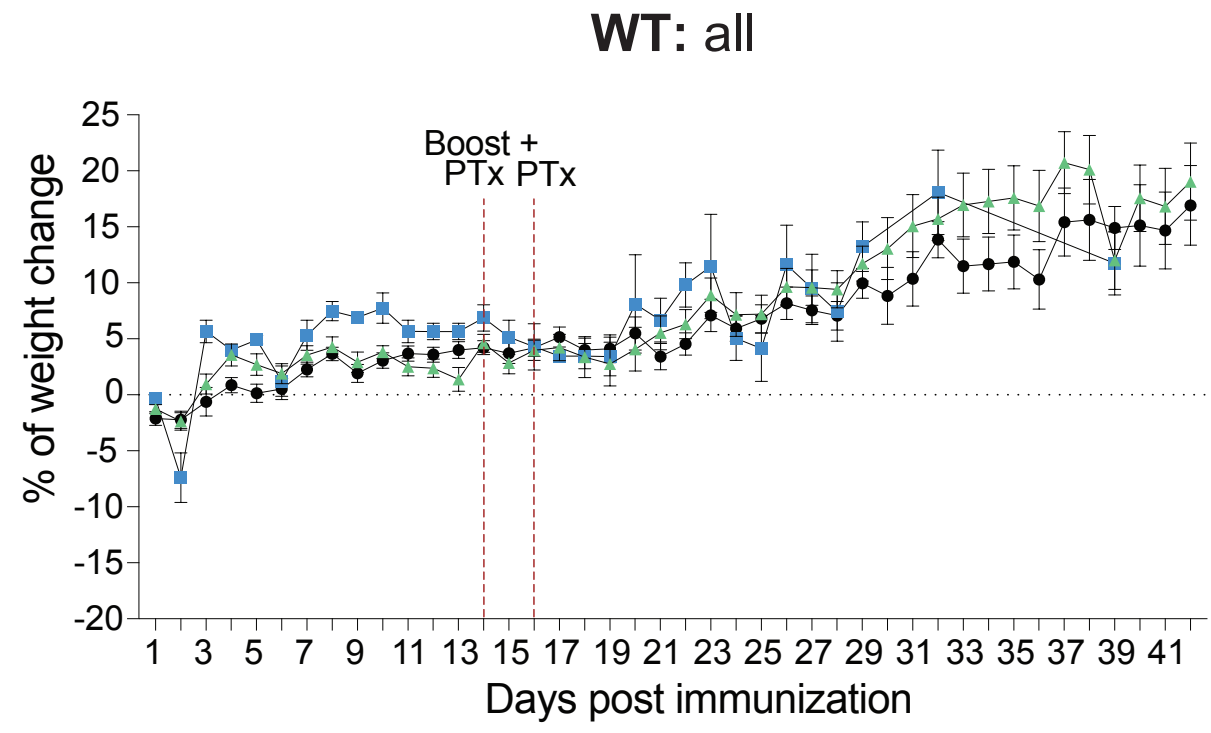

D

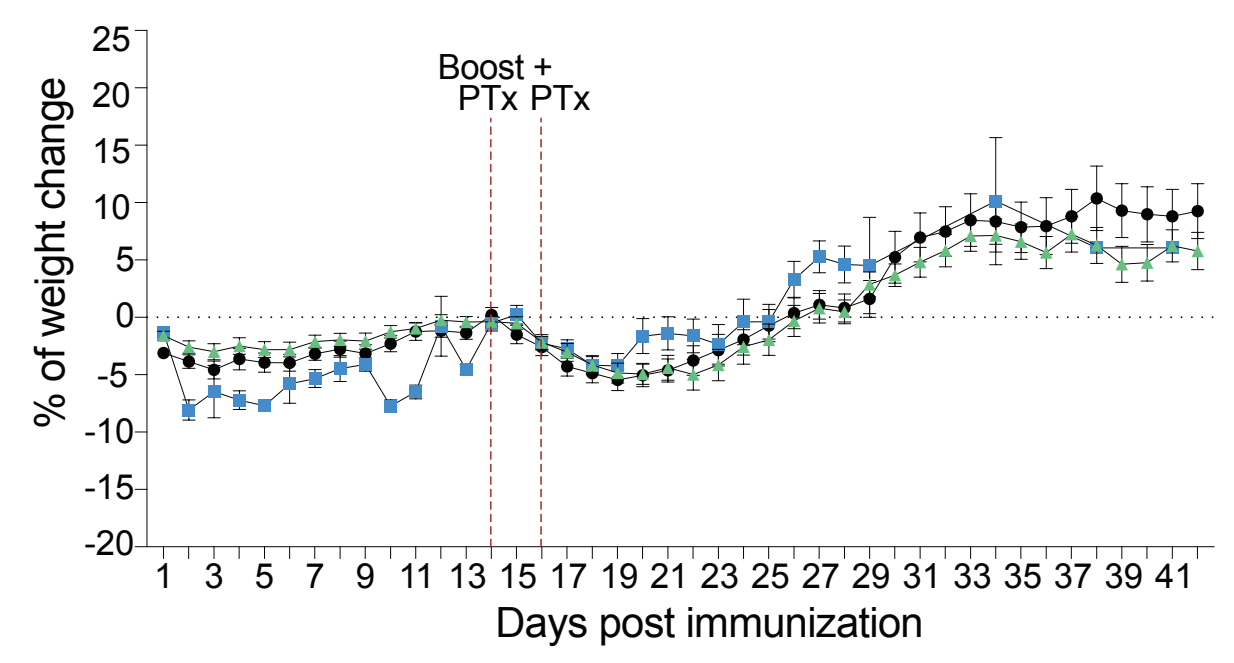

B
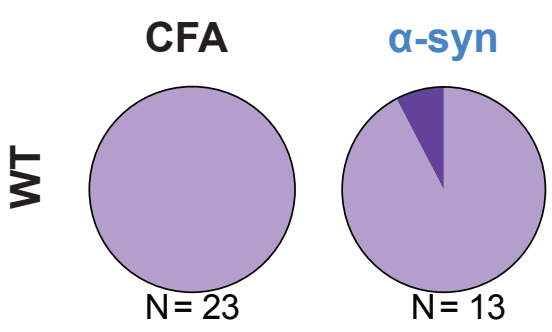

a-syn ${ }_{32-46}$
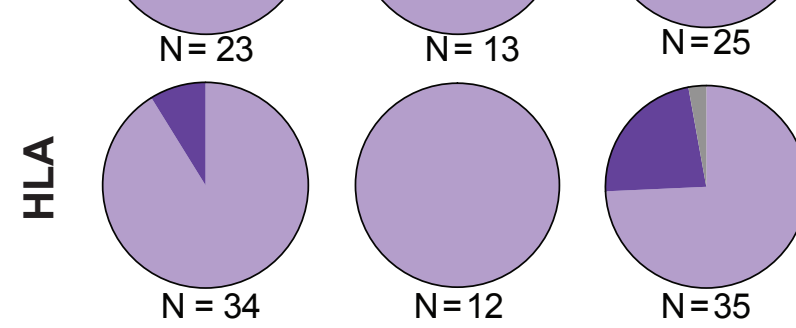

- CFA

$-\alpha-$-Syn

$\pm-\alpha-S_{32} n_{32-46}$

HLA: CFA and $\alpha-$ syn $_{32-46}$ sick mice

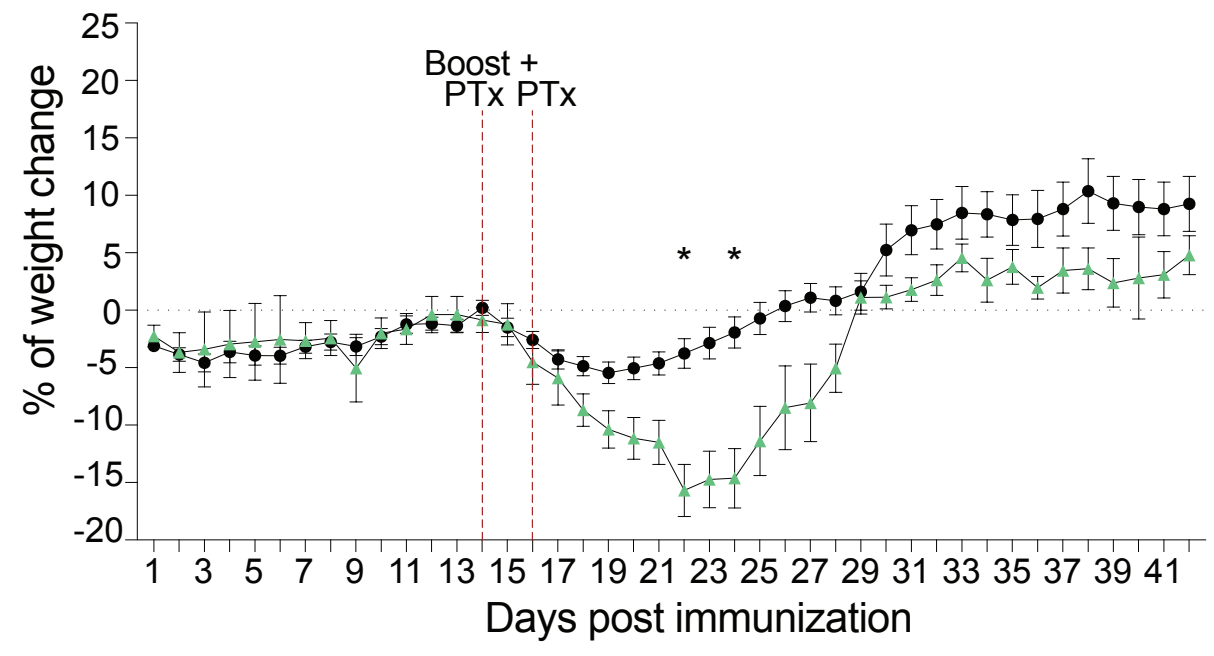


A

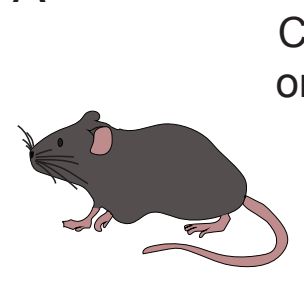

WT and HLA

\section{CFA + PBS}

or $\alpha-$ syn $_{32-46}$
Boost +

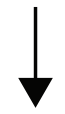

PTx PTx

B
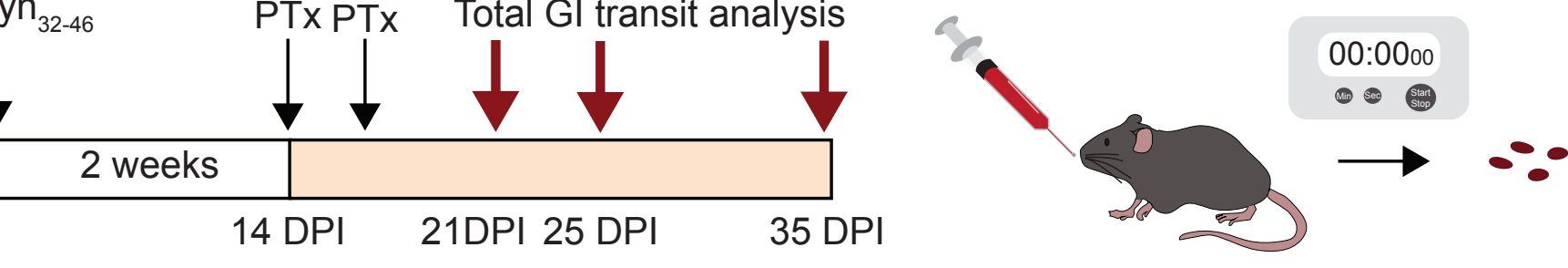

C

$21 \mathrm{DPl}$

D 21 DPI- sick aSyn ${ }_{32-46}$
E $25 \mathrm{DPI}$

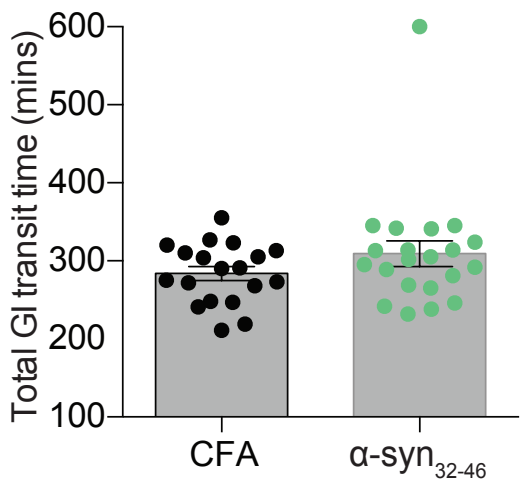

Immunization antigen
F

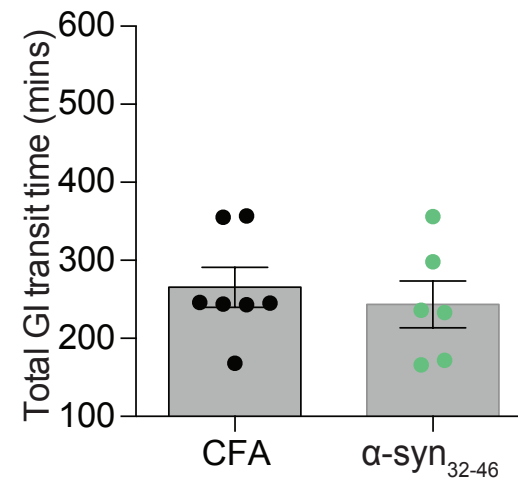

Immunization antigen
G

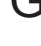

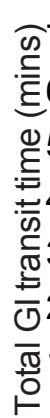

Immunization antigen

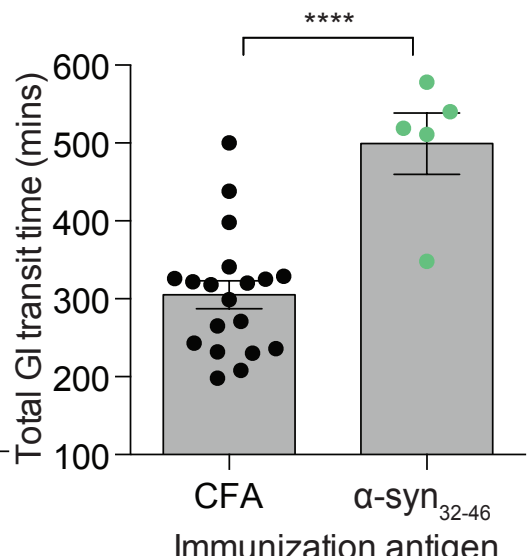

$\mathrm{H}$
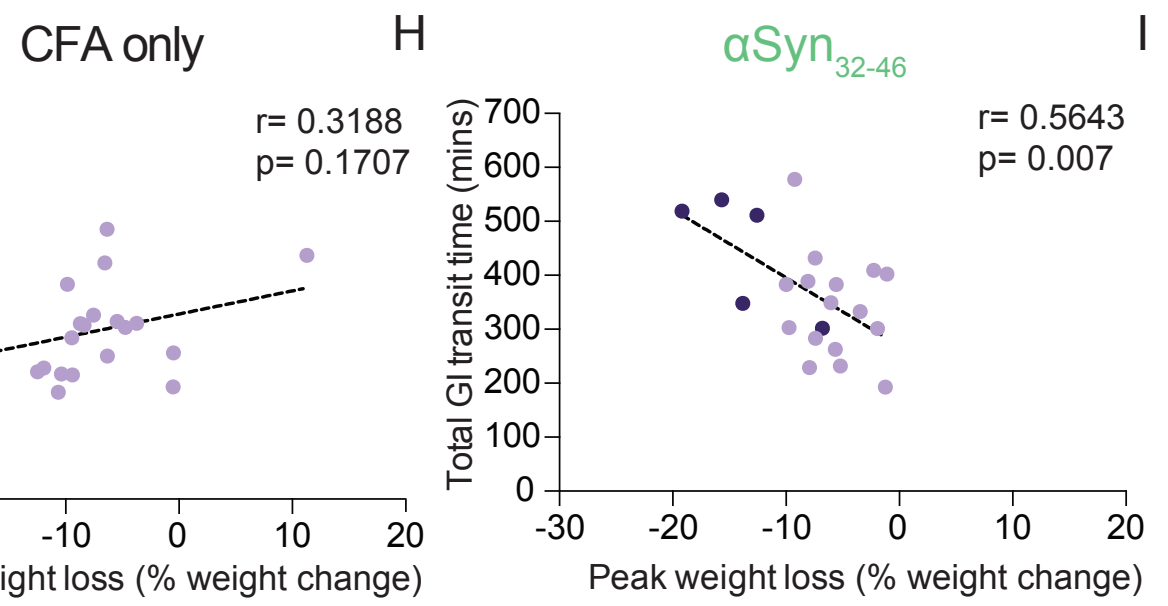

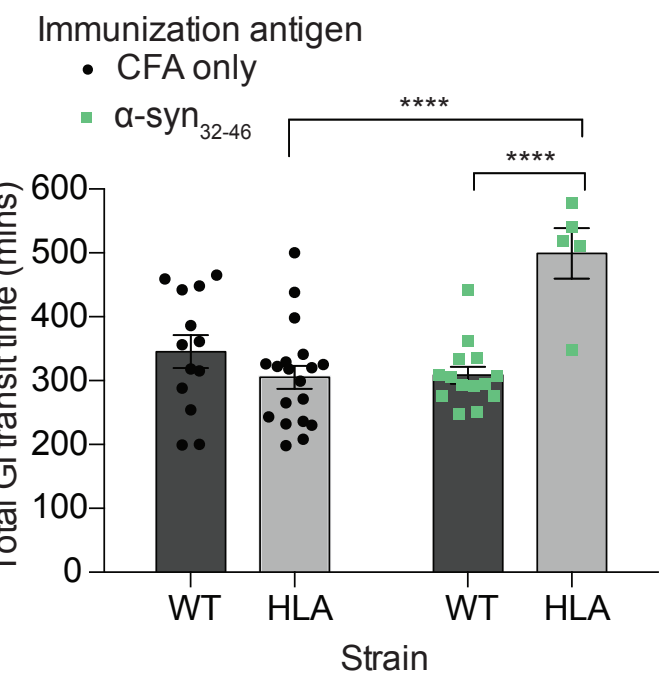


A bioRxiv preprint doi: https://doi.org/10.1101/2022.02.03.479014; this version posted FBpruary 5, 2022. The copyright holder for this preprint

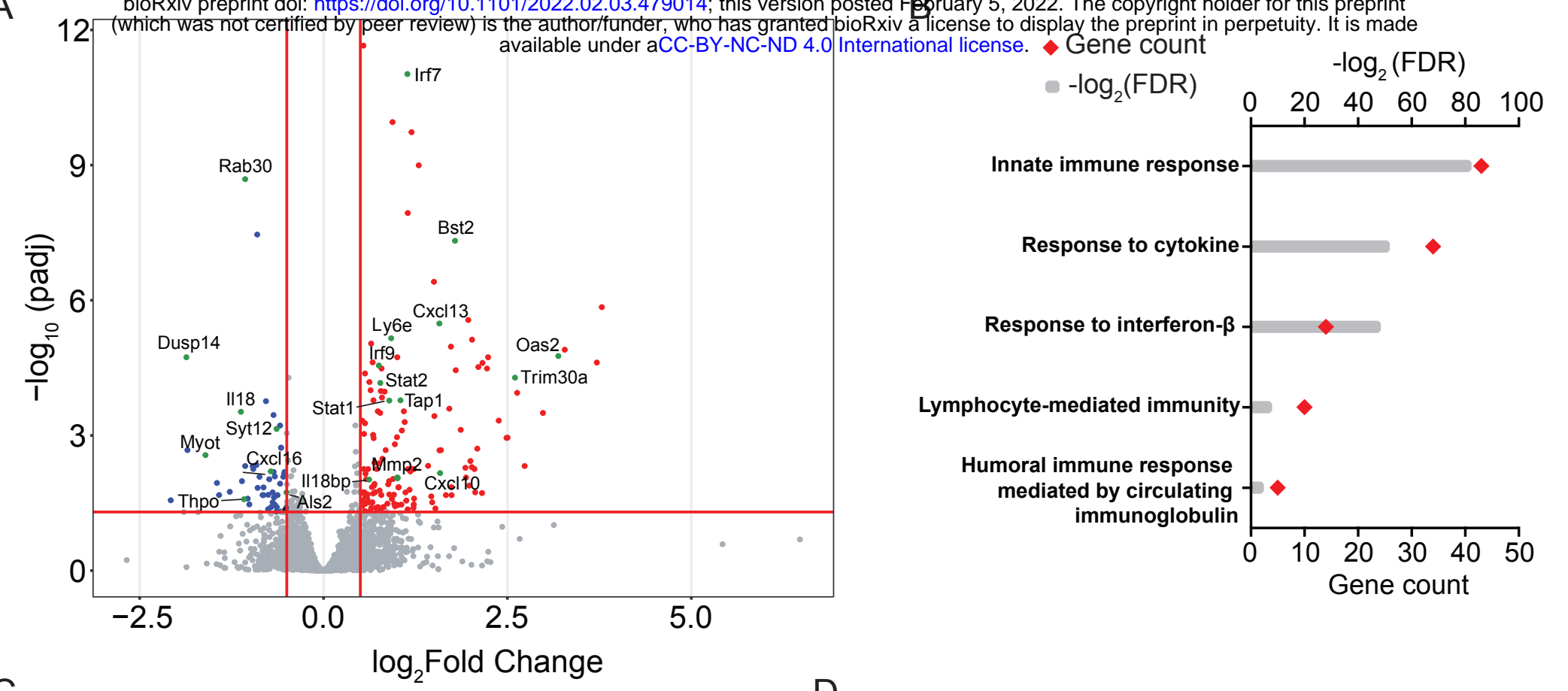

C

Innate immune response

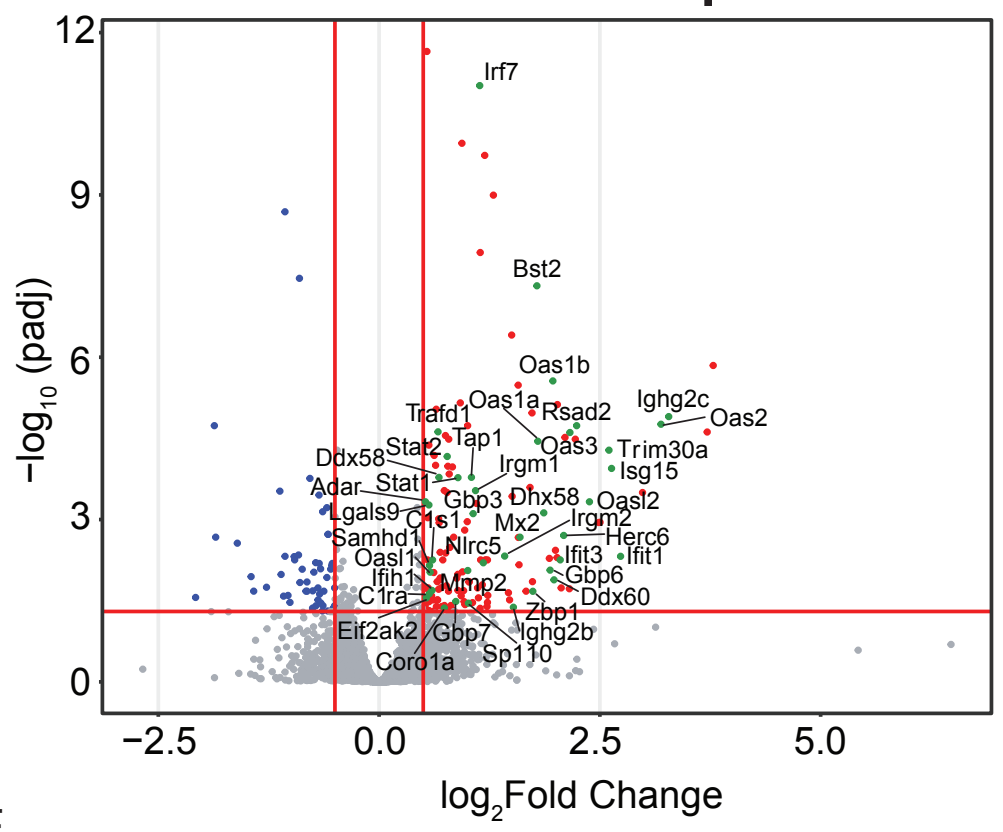

E

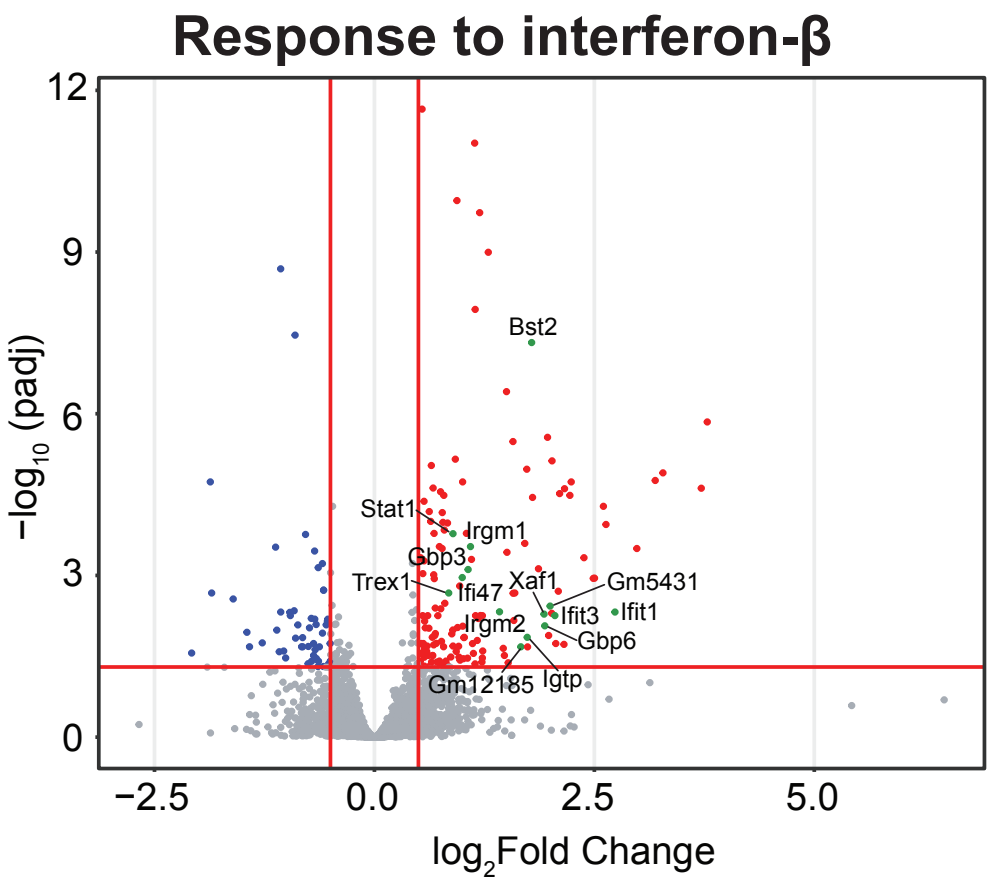

Response to cytokine

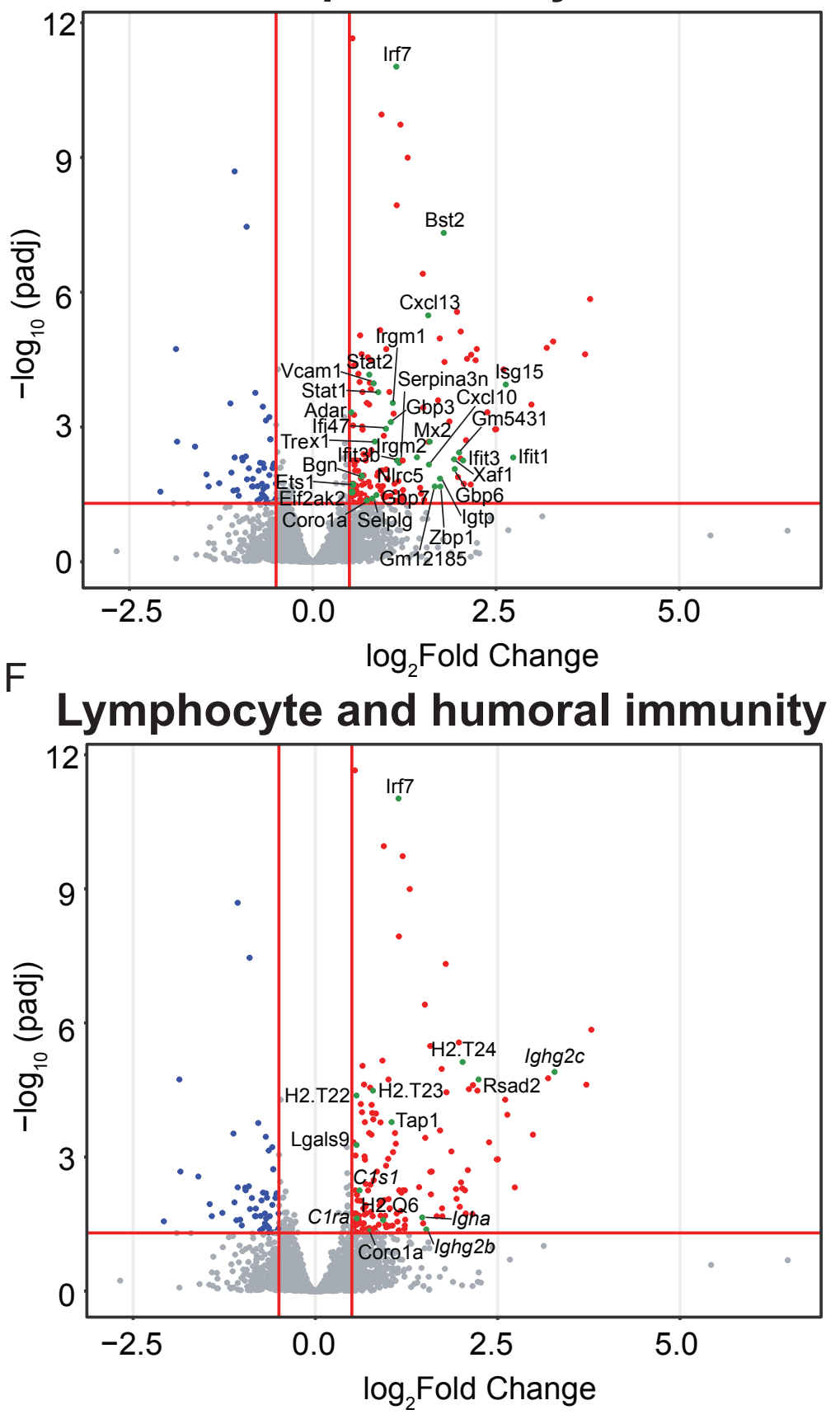




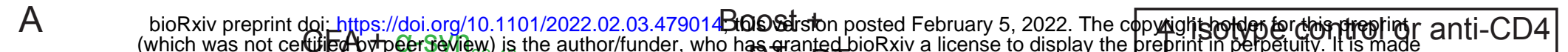
(which was not cetifited Aytpeerseview) is the author/funder, who hasfrantęg bioRxiv a license to disp
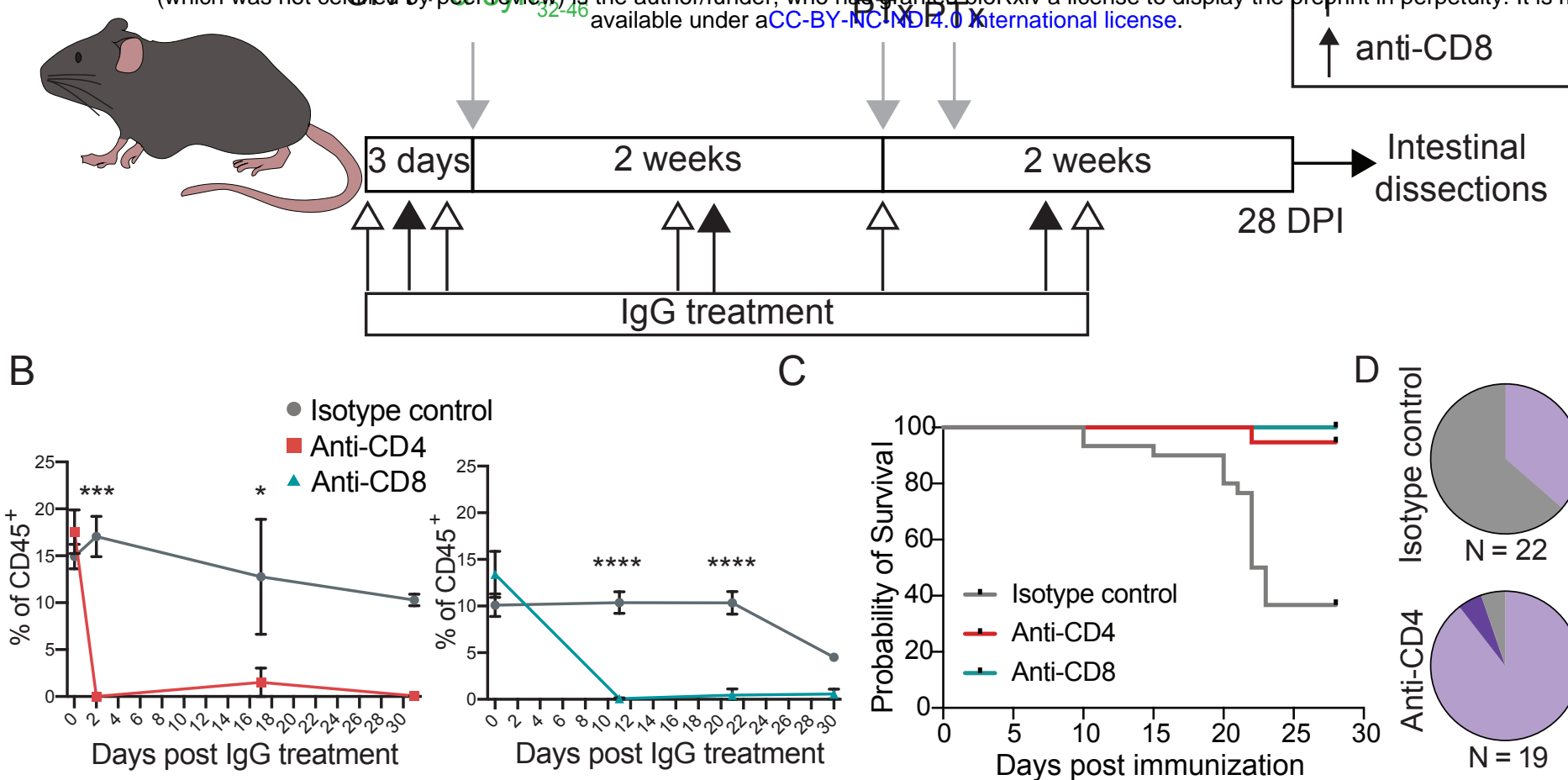

Days post IgG treatment
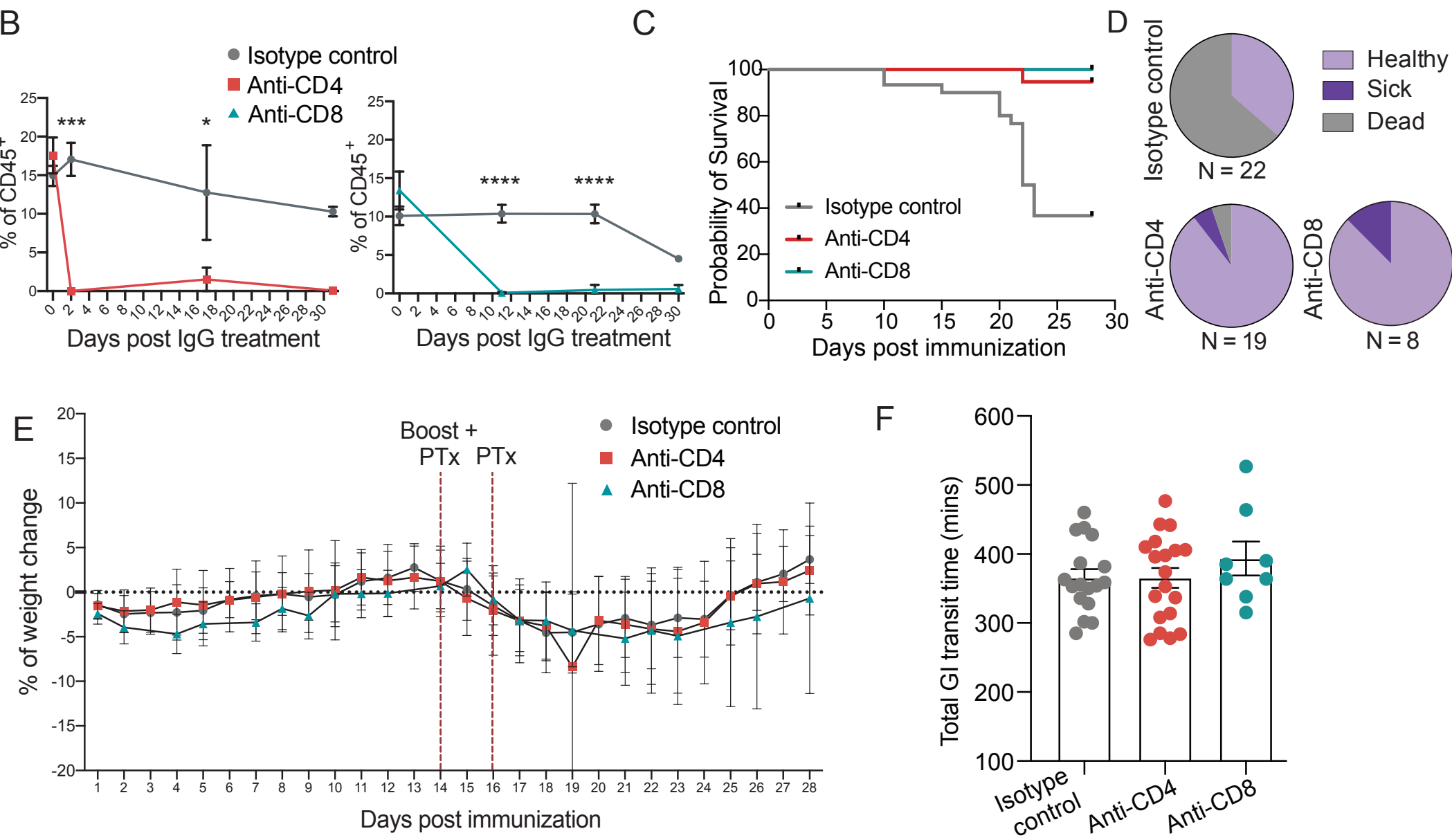

Days post immunization

Macrophages

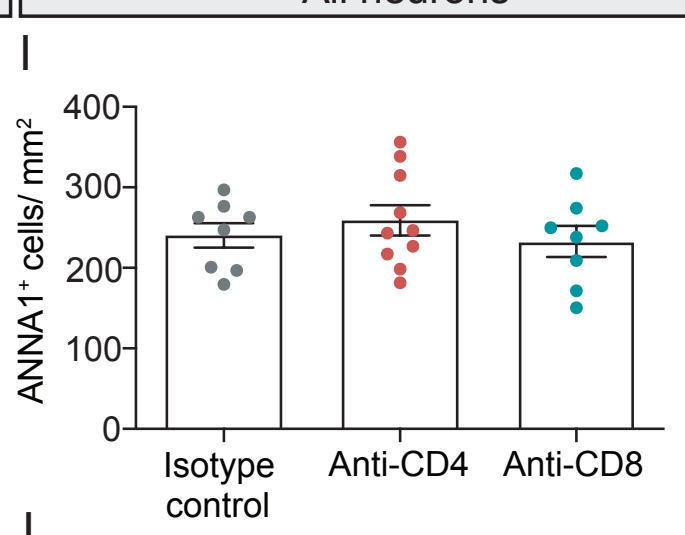

$\mathrm{J}$
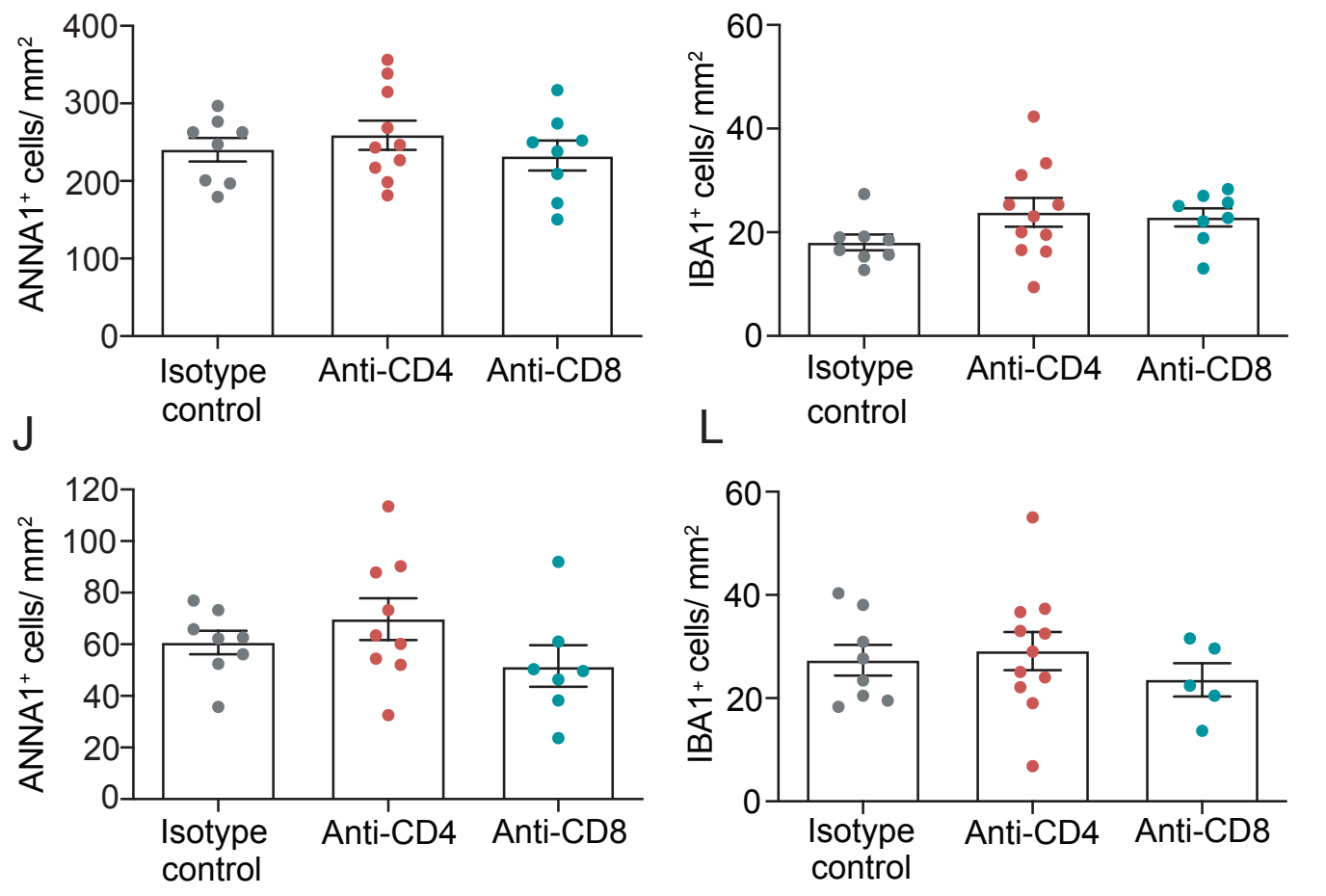
PD patients

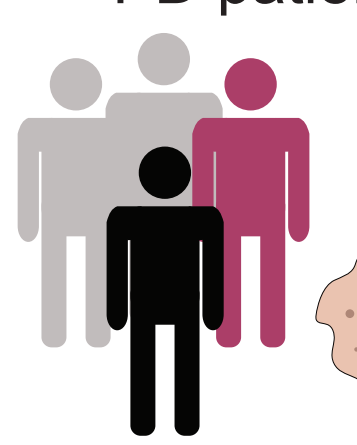

Humanized mouse model

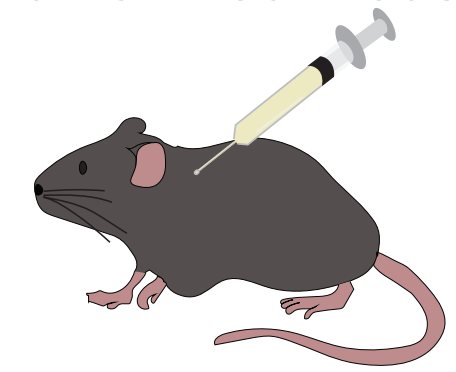

Dopaminergic neuron

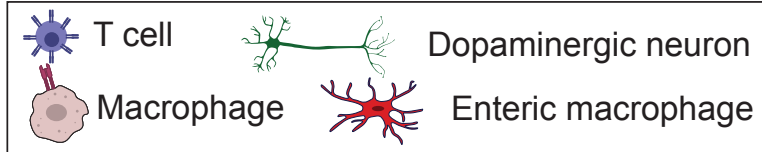

3. Brain infiltration and neurodegeneration

2. Enteric inflammation and neurodegeneration
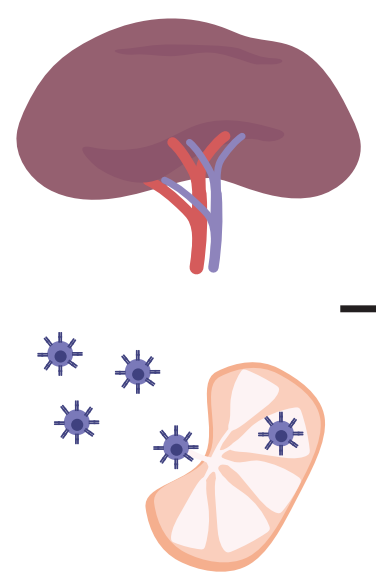

Mucosa
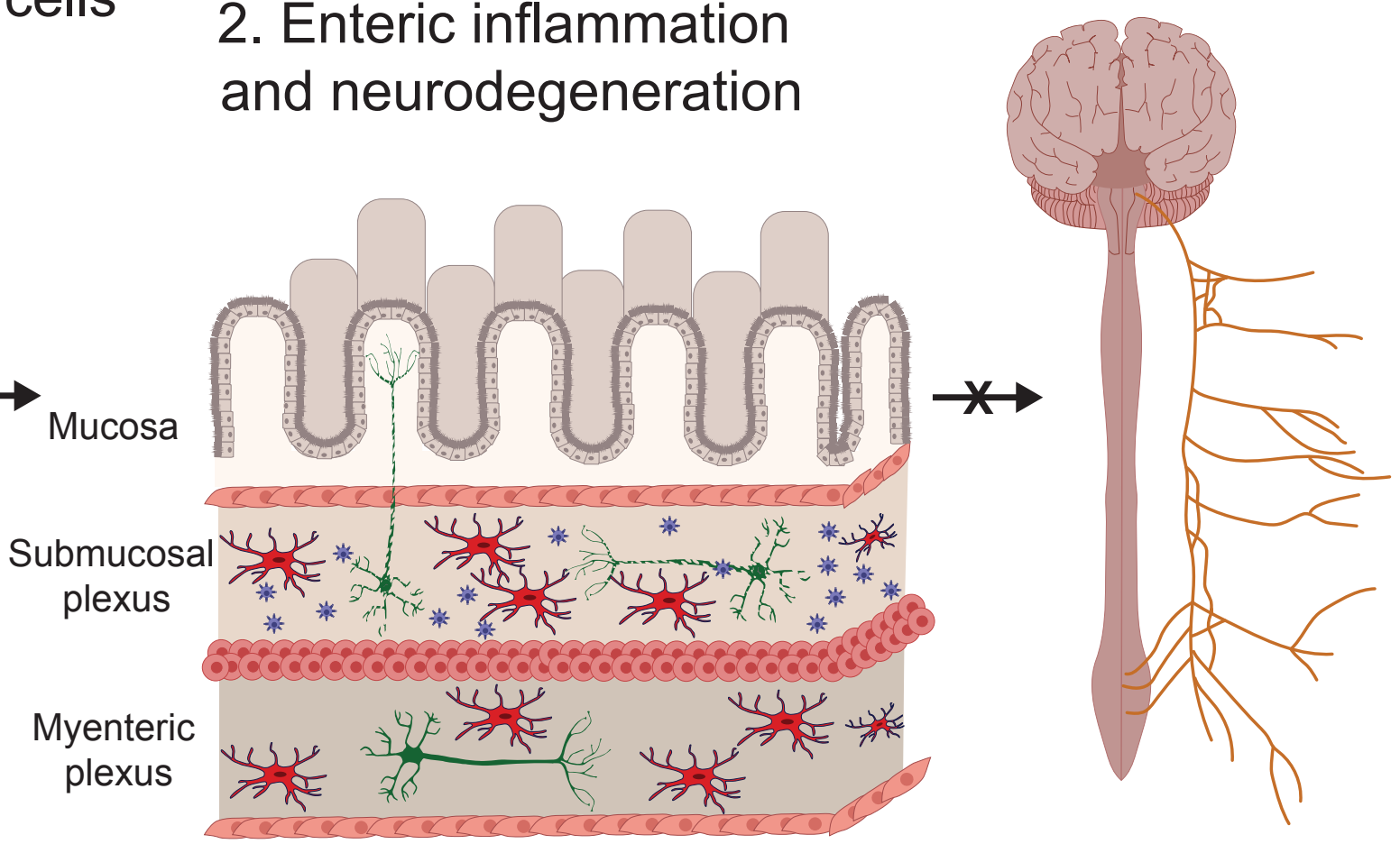